\title{
Chironomid-based reconstruction of Lateglacial summer temperatures from the Ech palaeolake record (French western Pyrenees)
}

\author{
L. Millet $^{\mathrm{a}, *}$, D. Rius ${ }^{\mathrm{a}, \mathrm{b}}$, D. Galop ${ }^{\mathrm{b}}$, O. Heiri ${ }^{\text {c }}$, S.J. Brooks ${ }^{\mathrm{d}}$ \\ a Laboratoire Chrono-Environnement, UMR 6249 CNRS, UFR Sciences et Techniques, Université de Franche-Comté, 25030 Besançon Cedex, France \\ b GEODE, UMR 5602 CNRS, Université de Toulouse - Le Mirail, Maison de la Recherche, 31058 TOULOUSE Cedex 9, France \\ ${ }^{\mathrm{c}}$ Institute of Plant Sciences and Oeschger Centre for Climate Change Research, University of Bern, CH-3013 Bern, Switzerland \\ d Department of Entomology, Natural History Museum, Cromwell Road, London SW7 5BD, UK
}

\section{A R T I C L E I N F O}

\section{Article history:}

Received 27 June 2011

Received in revised form 3 November 2011

Accepted 16 November 2011

Available online 3 December 2011

\section{Keywords:}

Lateglacial

Summer temperature

Western Pyrenees

Chironomids

\begin{abstract}
A B S T R A C T
Chironomid head capsules were extracted and identified in 52 samples along a sediment core retrieved from the Ech palaeololake, ( $710 \mathrm{~m}$ a.s.l. in the west-central Pyrenees). The pollen stratigraphy together with radiocarbon dates provided the basis for the chronology of the record. Since temperature changes were identified as one of the major determining factors for shifts in the Ech chironomid assemblages during the Lateglacial, July air temperatures were tentatively inferred from the chironomid record using a transfer function based on a combined Swiss and Norwegian calibration dataset. The model reconstructed July air temperatures between 10 and $13{ }^{\circ} \mathrm{C}$ during the Oldest Dryas, a two step increase in temperatures to 16 and $17.5^{\circ} \mathrm{C}$ during the first part of the Interstadial followed by a decrease to $16.5^{\circ} \mathrm{C}$ at the end of the Interstadial. The Ech record features three centennial-scale $1.5^{\circ} \mathrm{C}$ coolings during the Interstadial. Inferred temperatures decreased to $15-15.5^{\circ} \mathrm{C}$ during the Younger Dryas, and reached ca. $17^{\circ} \mathrm{C}$ at the beginning of the Holocene. The applicability of the combined Swiss-Norwegian transfer function to the Pyrenean fossil record was substantiated by the good statistics of the inference and the similar distribution of taxa with respect to temperature in the Alps and the Pyrenees. The reliability of the Ech record, including its chronology, was supported by its good concordance with other previously published chironomid-based lateglacial temperature reconstructions from Europe and the NGRIP $\delta^{18} \mathrm{O}$ record.
\end{abstract}

(C) 2011 Elsevier B.V. All rights reserved.

\section{Introduction}

During the transition from the Pleniglacial to the early Holocene, the so-called Lateglacial period, Europe was characterised by high climatic variability. Several major, rapid and high amplitude climate changes occurred within ca. 3000 yr. The onset of the Lateglacial Interstadial was marked by a sudden warming at ca. $14,700 \mathrm{cal} \mathrm{yr}$ BP. This warm phase was abruptly interrupted at ca. 12,700 cal yr BP by a millennium-long cold reversal, known as the Younger Dryas. At ca. 11,700 cal yr BP, the onset of warm conditions corresponded to the beginning of the Holocene, the present interglacial. Super-imposed on this millennial-scale climate variability, the Lateglacial was punctuated by a series of centennial-scale events such as the Gerzensee and the Aegelsee Oscillations during the Interstadial (Lotter et al., 1992) resulting in a complex spatio-temporal pattern of climate changes across Europe.

Disentangling the mechanisms of Lateglacial climate variability involving external and internal forcing factors is a major challenge for

\footnotetext{
* Corresponding author. Tel.: + 33381666 543; fax: + 33381666568. E-mail address: laurent.millet@univ-fcomte.fr (L. Millet).
}

the understanding of the earth's climate engine in the present context of global change. Within this framework, a spatial network of quantitative reconstructions of past climate changes is of major interest for assessing past climate gradients at the continental scale. Comparisons between reconstructions and model hindcasts can ultimately serve to improve climate model performance and forecasting.

Quantitative reconstructions of past climate changes are still unevenly distributed throughout Europe. Renssen and Isarin (2001) pointed out the lack of Lateglacial quantitative reconstructions for the southern part of the continent. Since then, new data were produced from Mediterranean sediments (e.g. Dormoy et al., 2009) and sediment records from lakes in the Southern Alps (Heiri et al., 2007a, b; Larocque and Finsinger, 2008; Ortu et al., 2008). Nevertheless, quantitative estimations of climate parameters remain rare for many areas of Europe and more specifically for the south-western part of the continent.

Among biological proxies from lake sediments, chironomid assemblages are viewed as one of the most promising climatic indicators (Battarbee, 2000). Most of the larvae of Chironomidae (Insecta: Diptera) live at the bottom of lakes. Chitinous remains (head capsules) produced during larval development are well preserved in sediment archives. Changes in past community composition through 
time are reconstructed after extraction and identification of head capsules along sediment cores. In the pioneering work of Walker et al. (1991) followed by other studies in Europe (Brooks, 2006), temperature was identified as one of the key factors affecting chironomid assemblage distribution at a large geographical scale. A wide consensus exists that the large temperature changes registered during the Lateglacial had a distinct influence on chironomid assemblages of shallow lakes, although several other environmental and limnological factors may also have had a potential impact on the fauna (Walker, 2001). Thanks to the development of transfer functions based on the modern distribution of chironomids among a large set of lakes, summer temperature can be inferred from past changes in chironomid assemblages. The accuracy and reproducibility of this approach for Lateglacial temperature reconstructions is now broadly demonstrated (Brooks, 2006; Lang et al., 2010).

This study is the first attempt to reconstruct chironomid assemblages from a lake record in the Pyrenees (South-western France) and infer quantitatively summer temperatures during the Lateglacial in a region where such reconstructions are still lacking. To date, there is no transfer function available in the study area for inferring summer air temperature. This lack of local calibration data was circumvented by using a newly developed transfer function based on a large number of lakes in the northern and central Alps of Switzerland and in Norway (Heiri et al., 2011).

The aim of this work is to (i) unravel the response of lateglacial chironomid assemblages to climate changes in the Pyrenees, (ii) assess the applicability of a mixed Swiss-Norwegian transfer function to a Pyrenean fossil record and (iii) evaluate the consistency of the temperature reconstruction by means of comparison with other climate record from Europe and Greenland.

\section{Study site}

The mountain chain of the Pyrenees spreads from the Atlantic Ocean to the Mediterranean Sea (Fig. 1). This intermediate geographical position implies the existence of a strong W-E climatic and ecological gradient throughout the chain from the Atlantic climate prevailing in the western part to Mediterranean climate in the eastern zone. The study site $\left(43^{\circ} 04^{\prime} 58.74 \mathrm{~N} ; 0^{\circ} 05^{\prime} 38.53 \mathrm{~W}\right.$, $710 \mathrm{~m}$ a.s.l.) is located in the west-central Pyrenees (Fig. 1). The

a

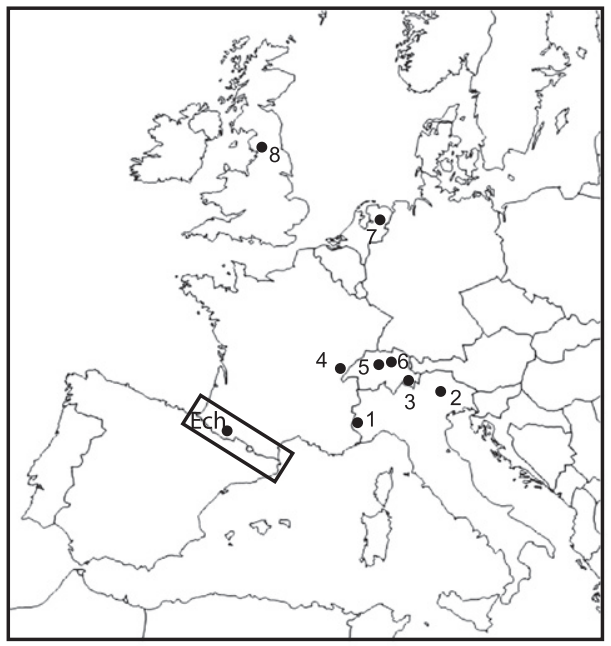

b

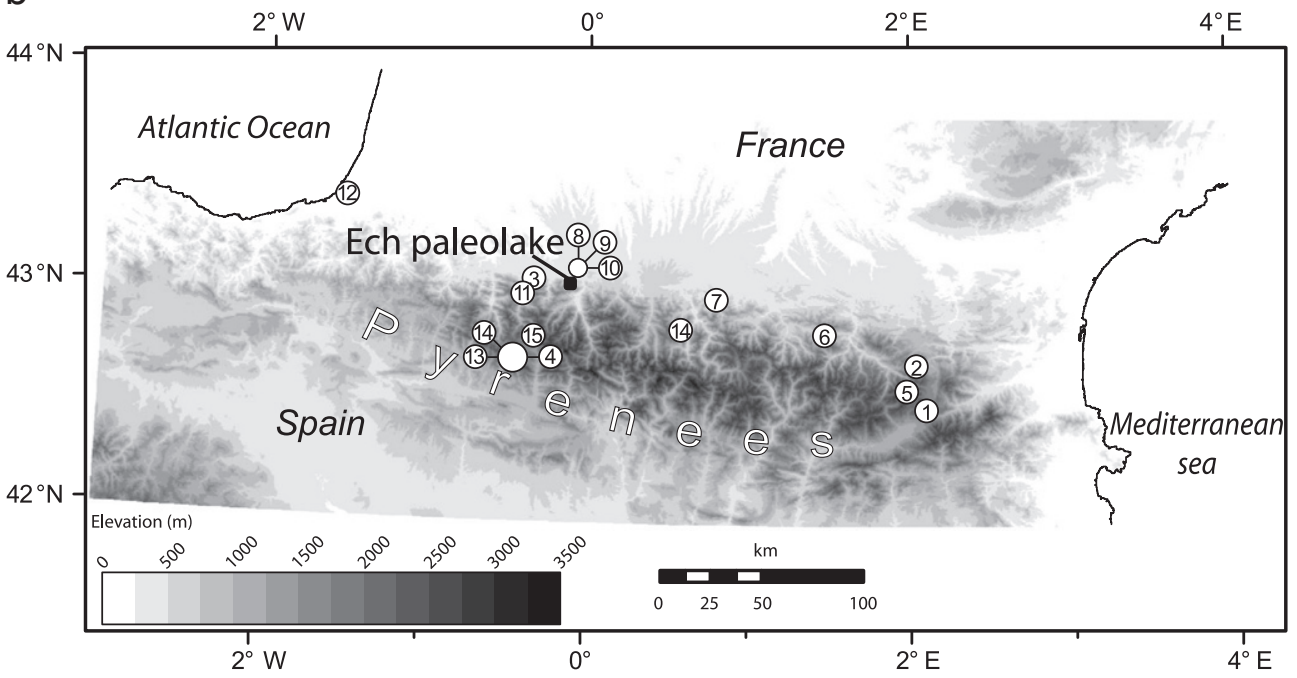

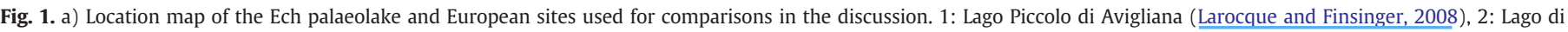

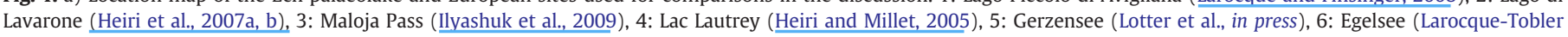

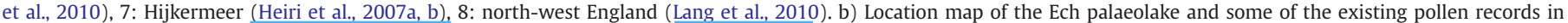

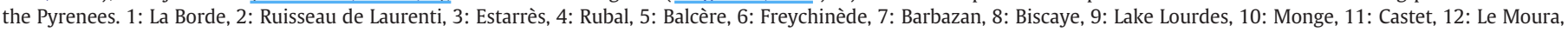

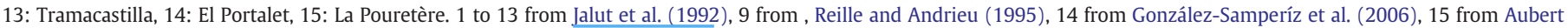
et al. (2004). 
study area is characterised by a mountainous Oceanic climate with mean annual precipitation of $1200 \mathrm{~mm}$ (Météo France data, 1931-2006). The mean summer temperature for the site can be estimated to ca. $17.1^{\circ} \mathrm{C}$ from the altitudinal correction of the meteorological data monitored at Lourdes (weather station located at $410 \mathrm{~m}$ a.s.l.) using a lapse rate of $0.5^{\circ} / 100 \mathrm{~m}$ elevation (AgustìPanareda and Thompson, 2002). Regional vegetation consists of Atlantic-type oak forest mainly dominated by Quercus (Q. robur and Q. pyrenaica) with Corylus and Betula. The north-facing slopes (up to $900 \mathrm{~m}$ a.s.l.) are covered by a mixed beech-oak forest (Fagus sylvatica), which is the dominant vegetation type of the bioclimatic hill stage in the area (Dupias, 1985).

The col d'Ech peat bog is $200 \mathrm{~m}$ wide and $280 \mathrm{~m}$ long. It is a former small glacial lake which is located on a small plateau dammed by a recessional moraine at the south and by a $200 \mathrm{~m}$ high south-facing calcareous slope at the north.

\section{Material and methods}

In 2006, a total of 10 overlapping $1 \mathrm{~m}$ long sediment sections were retrieved using a Russian corer ( $120 \mathrm{~mm}$ in diameter) at the centre of the Ech peat bog. All sections were transferred to a PVC liner and kept at $6{ }^{\circ} \mathrm{C}$ in a cold-room.

A composite five metre long core was constructed from magnetic susceptibility and gamma density profiles acquired at high resolution (5 mm interval) using a Geotek Multi-Sensor Core device. The lithological profile is typical for a palaeolake basin gradually filled up by sediment and the subsequent development of a peat bog. Along the core, peat accumulation begins at $330 \mathrm{~cm}$ below the surface overlying lacustrine deposits consisting of silt, clay and coarse organic remains in changing proportions.

The whole sediment profile was sampled at $5 \mathrm{~cm}$ intervals for pollen analysis ( 30 samples). Some additional levels ( 3 samples) were analysed between $380 \mathrm{~cm}$ and $390 \mathrm{~cm}$ i.e. within a sediment unit corresponding to the Younger Dryas (see below). Standard methods involving $\mathrm{NaOH}(10 \%), \mathrm{HCl}, \mathrm{HF}(30 \%)$, and acetolysis treatment (5 min) were applied for pollen preparation. The pollen preservation was good and concentrations were always sufficient to count over 450 terrestrial pollen grains per slide. Pollen percentages are based on the pollen sum of arboreal (AP) and non-arboreal (NAP) pollen grains, excluding Alnus, Cyperaceae, aquatic taxa and fern spores.

Chironomid remains and Loss-On-Ignition (LOI) were analysed in the core section covering the Lateglacial and the early Holocene i.e. between $370 \mathrm{~cm}$ and $476 \mathrm{~cm}$ below the surface (as indicated by main pollen changes in reference to regional vegetation changes during the Late-glacial and early Holocene).

LOI was performed on wet samples taken contiguously at $1 \mathrm{~cm}$ intervals between 369 and $422 \mathrm{~cm}$ and at 3 to $7 \mathrm{~cm}$ intervals until $476 \mathrm{~cm}$. 1.5 to $4 \mathrm{~g}$ (constant volume) of wet sediment was dried at $105^{\circ} \mathrm{C}$ overnight and then ignited at $550{ }^{\circ} \mathrm{C}$ for $4 \mathrm{~h}$ with the weight loss measured after each stage (Heiri et al., 2001). LOI is expressed as a percentage of weight loss in dried sediment.

Chironomids were analysed in 52 samples of $1 \mathrm{~cm}$ thickness, contiguously between $382 \mathrm{~cm}$ and $421 \mathrm{~cm}$ and at 3 to $7 \mathrm{~cm}$ intervals within section $421-476 \mathrm{~cm}$ and $370-382 \mathrm{~cm}$. Head capsules (HC) were extracted from the sediment following the procedure described by Walker (2001) including $\mathrm{HCl}(10 \%)$ and $\mathrm{KOH} \mathrm{(10 \% )} \mathrm{treatment} \mathrm{and}$ sieving at 100 and $200 \mu \mathrm{m}$. Chironomid remains were hand-sorted from the sieving residue under 40 to $70 \times$ magnification. HC were mounted ventral side up on microscope slide using Aquatex@ mounting agent. Identification of specimens to the genus- or species/grouplevel followed mainly Wiederholm (1983) and Brooks et al. (2007) and was performed under 100 to $1000 \times$ magnification. The relative abundance of each taxon as a percentage of the total number of specimens was calculated in each sample. Only taxa occurring in at least two samples, with a maximum relative abundance of more than $2 \%$, were included for further analysis.

Stratigraphic diagrams of the relative abundance of pollen and chironomid taxa were produced using TGView v. 2.0.2 (Grimm, 2004). The chironomid assemblage zones were defined from a stratigraphically constrained cluster analysis performed by Coniss (Grimm, 2004). Ordinations (DCA, CA and CCA) were performed using ade 4 (Chessel et al., 2004), the Vegan packages for $\mathrm{R}$ and Canoco for Windows version 4.52 (ter Braak and Smilauer, 2002).

Chironomid-inferred July air temperatures were reconstructed using the chironomid- temperature transfer-function described by Heiri et al. (2011). This transfer-function is based on a modern calibration dataset from the Alpine and Norwegian regions and Weighted Averaging-Partial Least-Squares regression (WA-PLS; ter Braak and Juggins, 1993; ter Braak et al., 1993). The overall Root Mean Square error of Prediction (RMSEP) of the transfer-function and estimated standard errors of prediction were calculated for the individual fossil samples using bootstrapping (9999 bootstrap cycles; Birks et al., 1990).

Fossil assemblages with a squared $\chi^{2}$-distance to the most similar assemblage in the modern calibration dataset larger than the 2 nd and the 5 th percentile of all squared $\chi^{2}$-distances in the modern data were identified as samples with 'no close' and 'no good' analogue, respectively (Birks et al., 1990; Jones and Juggins, 1995; Heiri et al., 2003). Fossil samples were added passively in a canonical correspondence analysis (CCA) of the modern calibration data with July air temperature as the only constraining parameter. Fossil samples with a residual distance to the first CCA axis larger than the 90th and 95th percentile of the residual distances of all the modern samples were identified as samples with a 'poor fit' and a 'very poor fit' with temperature, respectively (Birks et al., 1990). Chironomid taxa with a Hill's N2 (Hill, 1973) below 5 in the calibration data were considered to be rare in the modern dataset (Heiri et al., 2003). WA-PLS, Hill's N2 values, and squared $\chi^{2}$-distances were calculated with the programme C2 (Juggins, 2003) version 1.4.3. All calculations are based on square-root transformed percentage abundances.

Between $320 \mathrm{~cm}$ and $455 \mathrm{~cm}, 7$ samples of terrestrial material (2) or bulk sediment (5) were submitted for AMS dating to the Poznan Radiocarbon Laboratory (Table 1 ). The ${ }^{14} \mathrm{C}$ AMS dates were calibrated to years before present (cal yr BP) with Calib v. 6.0.1 (Stuiver and Reimer, 1993) using the Intcal09 calibration curve (Reimer et al., 2009).

\section{Results}

\subsection{Lithology and LOI}

Between 360 and $500 \mathrm{~cm}, 6$ sediment units (SU) were identified based on changes in lithology (i.e. texture, grain size and colour) and organic content of the sediment (Fig. 2):

At the lowest part of the record, SU $1(500-485 \mathrm{~cm})$ consisted of inorganic proglacial blue clay. SU $2(485-450 \mathrm{~cm})$ was characterised by light grey silty-clay with low organic content ( $\mathrm{LOI}<8 \%$ ). Sediments between 450 and $420 \mathrm{~cm}$ (SU 3) consisted of grey-brown silt with a

Table 1

Radiocarbon dates and material dated. * : rejected dates, see text for explanations.

\begin{tabular}{lclcc}
\hline $\begin{array}{l}\text { Depth } \\
(\mathrm{cm})\end{array}$ & $\begin{array}{l}\text { Radiocarbon age } \\
(\mathrm{BP})\end{array}$ & Material & $\begin{array}{l}\text { Calibrated age } \\
(2 \text { sigma) }(\text { cal yr BP })\end{array}$ & $\begin{array}{l}\text { Median } \\
\text { probability }\end{array}$ \\
\hline 329.5 & $7340 \pm 40$ & Bulk & $8020-8300$ & 8134 \\
380.5 & $9890 \pm 50$ & Bulk & $11,200-11,600$ & 11,292 \\
$390.5^{*}$ & $11,960 \pm 60$ & Bulk & $13,650-13,990$ & 13,819 \\
$390.5^{*}$ & $11,280 \pm 110$ & Charcoal & $12,885-13,385$ & 13,170 \\
$406.5^{*}$ & $12,730 \pm 80$ & Charcoal & $14,625-15,585$ & 15,093 \\
$420.5^{*}$ & $12,990 \pm 70$ & Bulk & $15,120-16,320$ & 15,610 \\
454.5 & $14,550 \pm 160$ & Bulk & $17,155-18,435$ & 17,695 \\
\hline
\end{tabular}




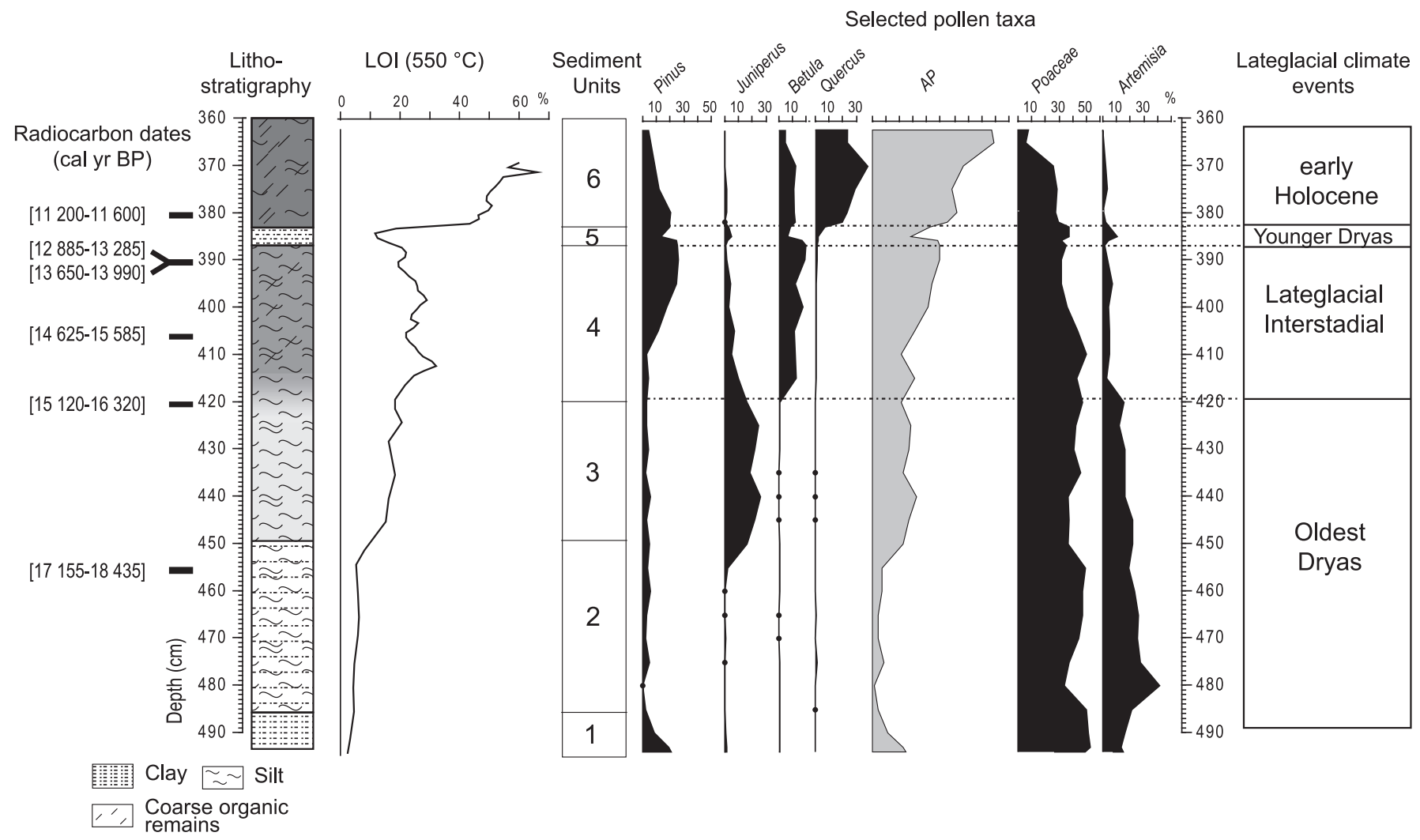

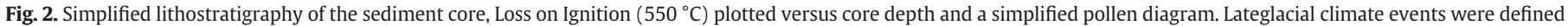
from the palynostratigraphy with reference to previous work in the region.

moderate organic content (LOI between 15 and 20\%) and some coarse unidentifiable organic fragments probably of aquatic origin. This section was overlain by a layer (SU 4: 420-387 cm) of brown organic silt (LOI between 20 and 30\%) with coarse unidentifiable organic aquatic remains. SU $5(387-383 \mathrm{~cm})$ was a thin layer of grey silty clay with moderate organic content ( $\mathrm{LOI}<18 \%)$. Between 383 and $360 \mathrm{~cm}$ (SU 6) sediments consisted of dark-brown silt with a high organic content (LOI between 40 and 50\%) and abundance of coarse organic remains.

\subsection{Pollen-stratigraphy and Lateglacial climate events}

The pollen stratigraphy between 500 and $360 \mathrm{~cm}$ is typical for the Lateglacial-early Holocene vegetation succession in the French Pyrenees as previously reconstructed by Jalut et al. (1988; 1992; 1996), Reille and Andrieu (1995) and Aubert et al. (2004). The boundaries of the main Lateglacial climate events can be defined from the pollen succession of the Ech record (Fig. 2).

In the lowest part of the sequence (i.e. during SU-1 and 2), pollen percentages are strongly dominated by Artemisia and Poaceae corresponding to steppe communities reconstructed in the Pyrenees before $14,500{ }^{14} \mathrm{C} \mathrm{BP}$ (around 17,500 cal yr BP, Jalut et al., 1992). The presence of arboreal pollen (AP) such as those of Pinus (up to $30 \%$ during SU-1), Quercus and Betula is probably linked to isolated stands or long distance transport of tree pollen from refugium areas (Jalut et al., 1992).

During SU-3, the pollen record is marked by the increase in the relative abundance of Juniperus and the converse slight decrease in Artemisia. This is in close agreement with numerous pollen diagrams from the French Pyrenees which indicated the development of a landscape dominated by Juniperus after $14,500{ }^{14} \mathrm{C}$ BP (around 17,500 cal yr BP, Jalut et al., 1992). Sediment units 1 to 3 can then be correlated to the Oldest Dryas.
The beginning of SU- 4 is characterised by the rapid rise in Betula, and the corresponding drop in Juniperus and Artemisia percentages, while Poaceae pollen remains abundant. The expansion of Betula is one of the key botanical events for the beginning of the Bølling in the area (Jalut et al., 1992). Betula and Poaceae were probably components of steppe or wooded steppe communities. In the second part (i.e. after $407 \mathrm{~cm}$ ), the pollen diagram features a strong increase in Pinus relative abundance (up to 30\%) and a parallel slight decrease in Poaceae percentages. This spread of Pinus is typical for the beginning of the Allerød (Jalut et al., 1992).

At the SU-4/SU-5 transition, the pollen diagram shows the decrease in Pinus and Betula percentages together with the increase in Artemisia, Poaceae and Juniperus. This re-advance in steppe elements and the opening up of the landscape is a characteristic feature of the Younger Dryas in the western French Pyrenees (Jalut et al., 1992; Aubert et al., 2004).

The onset of SU-6 is marked by a very sharp rise in AP with a strong dominance of Quercus pollen and the presence of Pinus and Betula while Artemisia percentages decrease. The increase in AP percentages and the expansion of Quercus indicate the beginning of the Holocene (Jalut et al., 1988; 1992).

\subsection{Radiocarbon age reliability and age/depth model}

In the Ech record, the coarse organic remains found within SU-3 to 6 consisted mainly of unidentifiable fibrous and translucent fragments and mosses. Despite the processing of a large number of sediment samples along the core (notably during the sieving for the chironomid analysis), unquestionably terrestrial remains (charcoal particles) were found in sufficient quantities for AMS radiocarbon dating in only two samples (Table 1). Other dates were produced from bulk sediment, implying a possible ageing effect due to the hard-water effect or allochtonous contamination by old carbon. The 
reliability of these radiocarbon dates must be carefully assessed under the light of the age determined for main lateglacial climate events and vegetation succession in the Pyrenees and in northwest Spain (Jalut et al., 1992; Reille and Andrieu, 1995; Allen et al., 1996; GonzálezSamperíz et al., 2006; Muñoz-Sobrino et al., 2007).

The radiocarbon date obtained from $454.5 \mathrm{~cm}([16,820-18,070]$ cal yr BP) is in agreement with the age of the spread of Juniperus which occurred after ca. $17,500 \mathrm{cal}$ yr BP $\left(14,500{ }^{14} \mathrm{C}\right.$ BP) in the French Pyrenees (Jalut et al., 1992). At $420.5 \mathrm{~cm}$, the radiocarbon date $([15,120-16,320]$ cal yr BP) seems slightly too old. Indeed, it just precedes the Oldest Dryas/Interstadial transition (at $419.5 \mathrm{~cm}$ ) which was dated to 14,700 cal yr BP in the Spanish Pyrenees (González-Samperíz et al., 2006), and between ca. 14,500 cal yr BP $\left(12,425{ }^{14} \mathrm{C}\right.$ BP, Allen et al., 1996) and 14,800 cal yr BP (MuñozSobrino et al., 2007) in northwest Iberia. The radiocarbon date obtained at $406.5 \mathrm{~cm}$ was rejected since it gave an aberrant age of 15,100 cal yr BP $([14,600-15,600]$ cal yr BP), which is several hundred years older than what would be expected for a sample from the Lateglacial Interstadial. At 390.5, two radiocarbon dates were obtained, a first from bulk material and a second from fine charcoal particles. The ages derived from bulk material (Table 1) imply a long break in sedimentation rate around $390 \mathrm{~cm}$ which is incompatible with both the sediment description and LOI; therefore this radiocarbon date was rejected. The age obtained from charcoal particles ([12,880-13,390] cal yr BP) seemed also slightly too old compared to the depth of the Interstadial/Younger Dryas transition $(387 \mathrm{~cm})$ which was dated to ca. $12,900 \mathrm{cal} \mathrm{yr} \mathrm{BP}$ in the study area ([12,660-13,230] cal yr BP, Lake Lourdes, Reille and Andrieu, 1995), and to $12,600 \mathrm{cal} \mathrm{yr}$ BP in the Spanish slope of the Central Pyrenees (González-Samperíz et al., 2006) and in northwest Iberia (MuñozSobrino et al., 2007). Several studies showed that radiocarbon dates performed on charcoal particles can produce an ageing effect by ranges of several decades to centuries (e.g. Gavin, 2001). The two remaining radiocarbon dates (at 329.5 and $380.5 \mathrm{~cm}$ ) are in agreement with ages found for the beginning of the Holocene in the study area (Lake Lourdes, Reille and Andrieu, 1995), in the Spanish Pyrenees and in northwest Spain (González-Samperíz et al., 2006; Muñoz-Sobrino et al., 2007).

A composite age/depth model using linear interpolation was built from the three accepted radiocarbon dates (Table 1) and ages estimated for the main Lateglacial transitions (Oldest Dryas/Interstadial, Interstadial/Younger Dryas) in the Pyrenees and northwest Iberia (Table 2 and Fig. 3).

\subsection{The chironomid record}

Chironomid head capsules were abundant in the whole record except for SU-1 where no remains were found. In 10 samples, counts were below the minimum of 45 remains usually recommended for palaeoenvironmental reconstruction (Heiri and Lotter, 2001). In only two samples (at 389.5 and $445.5 \mathrm{~cm}$ ) counts were less than 20 remains (Fig. 4). A total of 46 taxa were identified in the Ech record,

\section{Table 2}

Age (in cal yr BP) of the Oldest Dryas/Interstadial and Interstadial/Younger Dryas transition assessed based on previous studies in the region and selected age used to construct the age-depth model of Fig. 3.

\begin{tabular}{|c|c|c|c|c|}
\hline $\begin{array}{l}\text { Geographical } \\
\text { area }\end{array}$ & $\begin{array}{l}\text { Oldest } \\
\text { Dryas }\end{array}$ & $\begin{array}{l}\text { Lateglacial } \\
\text { Interstadial }\end{array}$ & $\begin{array}{l}\text { Younger } \\
\text { Dryas }\end{array}$ & Reference \\
\hline Spanish Pyrenees & \multicolumn{2}{|c|}{14,700} & 12,600 & $\begin{array}{l}\text { González-Samperíz } \\
\text { et al. (2006) }\end{array}$ \\
\hline Northwest Iberia & \multicolumn{2}{|c|}{ ca. 14,500} & ca. 12.650 & Allen et al. (1996) \\
\hline Northwest Iberia & \multicolumn{2}{|c|}{14,800} & 12,600 & $\begin{array}{l}\text { Muñoz-Sobrino } \\
\text { et al. (2007) }\end{array}$ \\
\hline Selected age & \multicolumn{2}{|c|}{14,700} & 12,600 & \\
\hline
\end{tabular}

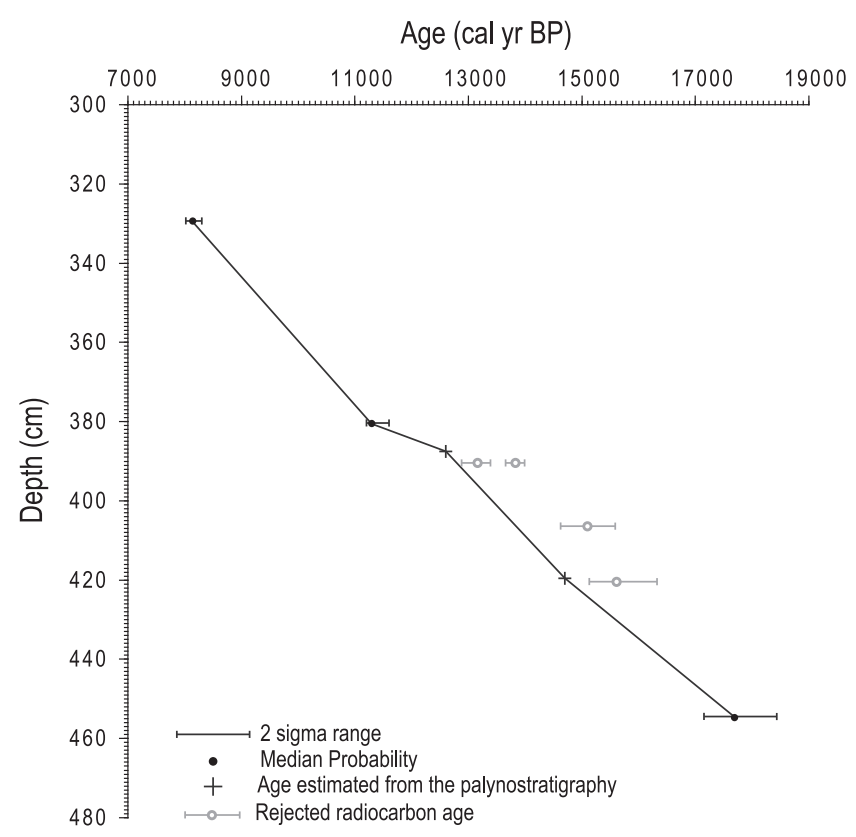

Fig. 3. Composite age-depth model for the Ech record built from a combination of 3 radiocarbon dates with ages inferred for the Oldest Dryas/Interstadial and Interstadial/ Younger Dryas transitions based on the palynostratigraphy with reference to previous work in the region (see Tables 1 and 2).

34 of them met the minimum frequency criteria and were included in further analyses.

Two main biozones (Ecz-1 and 2) and 5 subzones (from Ecz-2a to Ecz-2-e) were recognised within the Ech chironomid stratigraphy from the cluster analysis (Fig.4). A correspondence analysis (CA) was performed from the sample/taxa matrix (52 samples, 34 taxa). Major changes in sample scores along axis 1 and 2 (Fig. 4) corresponded to the main turn-over in chironomid assemblages as depicted by the cluster analysis. Characteristic taxa for each biozone and sub-biozone were defined from the projection of the samples and the taxa in the plane of the first two axis of the CA (Fig. 5). Only taxa with relative contribution $>15 \%$ to either axis one and/or two were considered and plotted.

\subsubsection{Ecz-1}

The samples of this biozone were clearly separated from the rest of the chironomid record in the CA biplot and were projected at the lower end of axis one. In descending order of relative abundance, the taxa characterising the biozone are: Chironomus anthracinus-type, Tanytarsus lugens-type, Micropsectra insignilobus-type, Orthocladius spp. and Psectrocladius sordidellus-type.

\subsubsection{Ecz-2}

As witnessed by the strong increase in sample scores along axis one, the Ecz-1/2 transition is marked by an important shift in the chironomid community. Dominant taxa of Ecz-1 sharply decline. Some of them like Micropsectra insignilobus-type and Psectrocladius sordidellus-type definitively disappeared from the chironomid record. The biozone Ecz-2 is characterised by the appearance of a number of new taxa. Considered as a whole, samples of Ecz-2 have high scores along axis one and are characterised by Tanytarsus pallidicornis type II, Polypedilum nubeculosum-type, Cladotanytarsus, Microtendipes, Glyptotendipes and Pseudochironomus.

The internal variability of the chironomid community is obvious through changes in the percentages of Tanytarsus pallidicornis-type II, Polypedilum nubeculosum-type, Chironomus anthracinus-type and Ablabesmyia and leads to the splitting of samples of Ecz-2 into two groups according to their scores along axis two of the CA. 


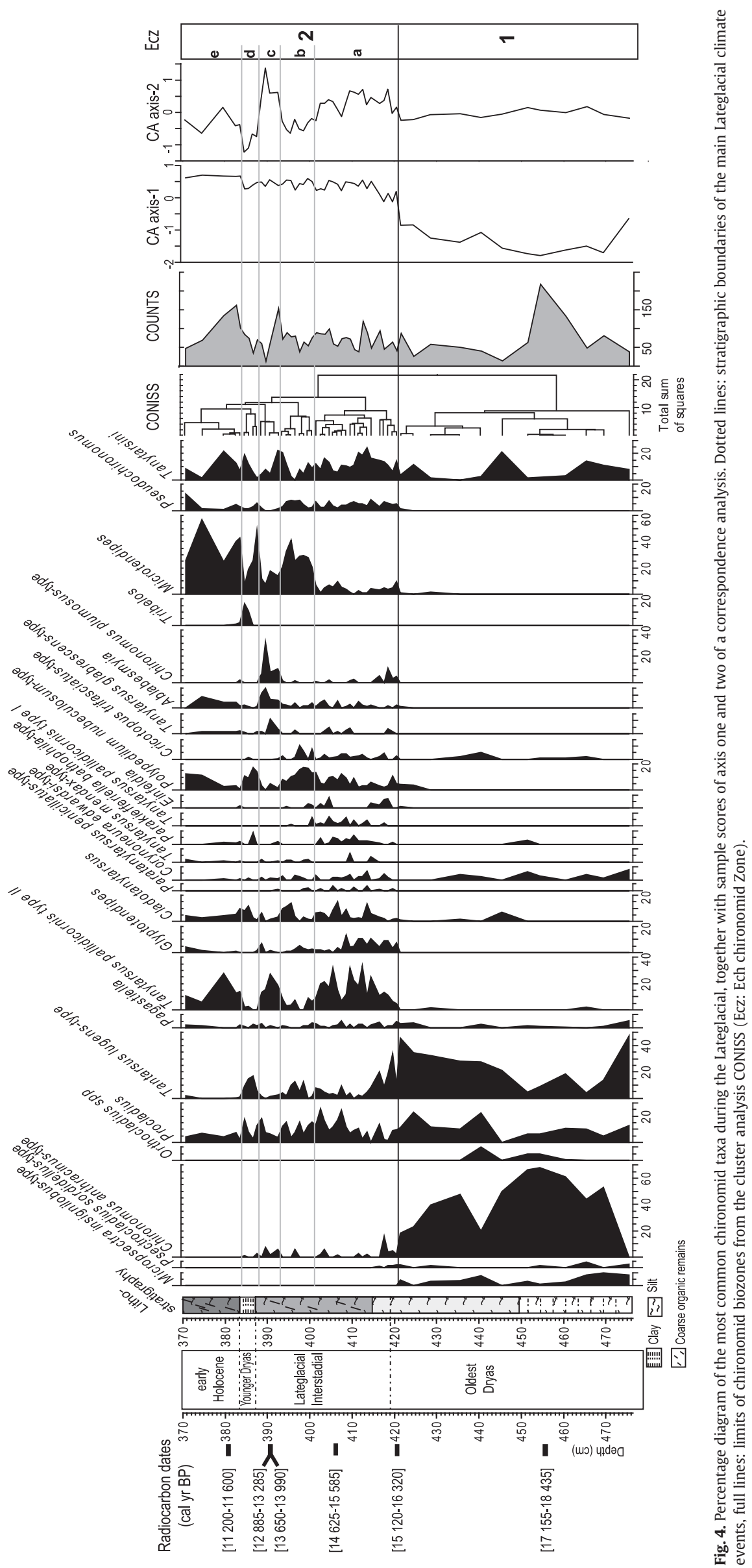




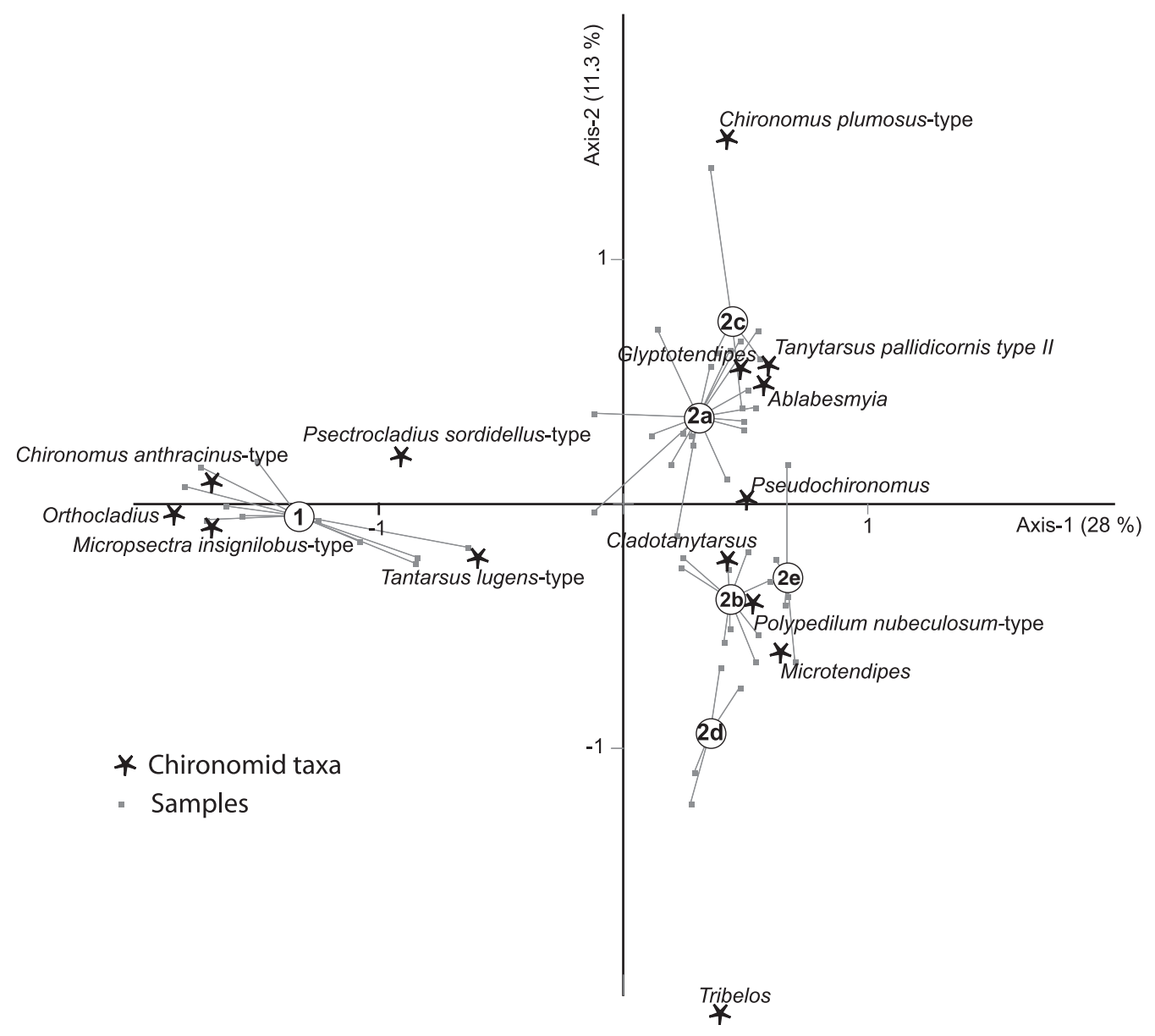

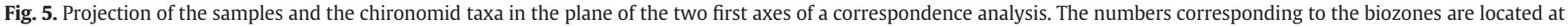
the barycentre of their constitutive samples. Only chironomid taxa with a relative contribution to axis one and/or two higher than 15\% are plotted. YD: Younger Dryas.

Samples of subzones $2 \mathrm{a}$ and $2 \mathrm{c}$ are plotted at the positive side of axis two. They are characterised by Tanytarsus pallidicornis-type II, Glyptotendipes and Ablabesmyia. Ecz-2c differs from 2a in the abundance of Chironomus plumosus-type (Figs. 4 and 5).

Samples of Ecz-2b and 2d, located at the negative end of the axis 2, are typified by high relative abundance of Microtendipes, and Polypedilum nubeculosum-type. Ecz-2d is further marked by slightly higher relative abundance of Tanytarsus lugens-type than Ecz-2b and the unique presence of Tribelos for the whole record. The samples of the biozone Ecz-2e are located at the high end of axis one. The assemblages are dominated by Microtendipes, Tanytarsus pallidicornis-type II and Polypedilum nubeculosum-type while Tanytarsus lugens-type and Chironomus anthracinus-type disappear.

\subsection{Quantitative inference of temperatures}

Chironomid-based temperature estimates were produced from the Ech record using a chironomid-temperature calibration dataset and transfer function based on 254 lakes sampled in Switzerland and Norway. The lakes cover a July air temperature gradient of $3.5-18.4^{\circ} \mathrm{C}$, a latitudinal gradient of $46.1-79.8^{\circ} \mathrm{N}$, an altitudinal gradient of 5-2815 $\mathrm{m}$ a.s.l. and include lakes on acid, basic and carbonaceous bedrock. This dataset was produced by taxonomic amalgamation of two regional calibration datasets from Norway and Svalbard (Brooks and Birks, 2001; 2004) and from the Swiss Plateau, the Jura Mountains and the northern, central and southern Swiss Alps (Heiri and Lotter, 2005; 2010) and describes the distribution of 154 chironomid taxa in respect to mean July air temperature (Heiri et al., 2011). Since the dataset includes lakes in temperate lowland, alpine and arctic environments it can be expected that it includes most environmental conditions prevailing during the Lateglacial period in Central and Northern Europe and in southern European mountain regions.

A chironomid-based inference model for temperature was developed from this calibration dataset using WA-PLS regression with the number of useful WA-PLS components evaluated according to Birks (1998). This resulted in a two component WAPLS regression model. When evaluated in the modern environment using bootstrapping techniques the inference model predicts mean July air temperature based on chironomid assemblages with a RMSEP of $1.55^{\circ} \mathrm{C}$ and a coefficient of determination of 0.84 .

The transfer function reconstructed July air temperature variability during the Lateglacial (Fig. 6) that can be summarised as follows:

Prior to 14,700 cal yr BP, i.e. during SU 2 and 3 corresponding to the Oldest Dryas, the summer temperatures were the coldest for the whole record and fluctuated between 10 and $13^{\circ} \mathrm{C}$ (mean: $11.7^{\circ} \mathrm{C}$ ). At the Oldest Dryas/Lateglacial Interstadial transition, the transfer function reconstructed an abrupt increase in July air temperatures from ca. $11^{\circ} \mathrm{C}$ to ca. $16{ }^{\circ} \mathrm{C}$. The temperature record displayed a high internal variability during the Lateglacial Interstadial. In a first step, temperature continued to increase to reach around $17.5^{\circ} \mathrm{C}$ at $\mathrm{ca}$. $14,000-14,200$ cal yr BP. The following period was marked by a gradual cooling of around $1{ }^{\circ} \mathrm{C}$ interrupted by 3 short and rapid cold events of $1.5^{\circ} \mathrm{C}$ magnitude at ca. 13,100 cal yr BP, 13,600 cal yr BP and 13,900 cal yr BP. At the Lateglacial Interstadial/Younger Dryas transition, inferred July air temperature shifted from $16.8^{\circ} \mathrm{C}$ to values 


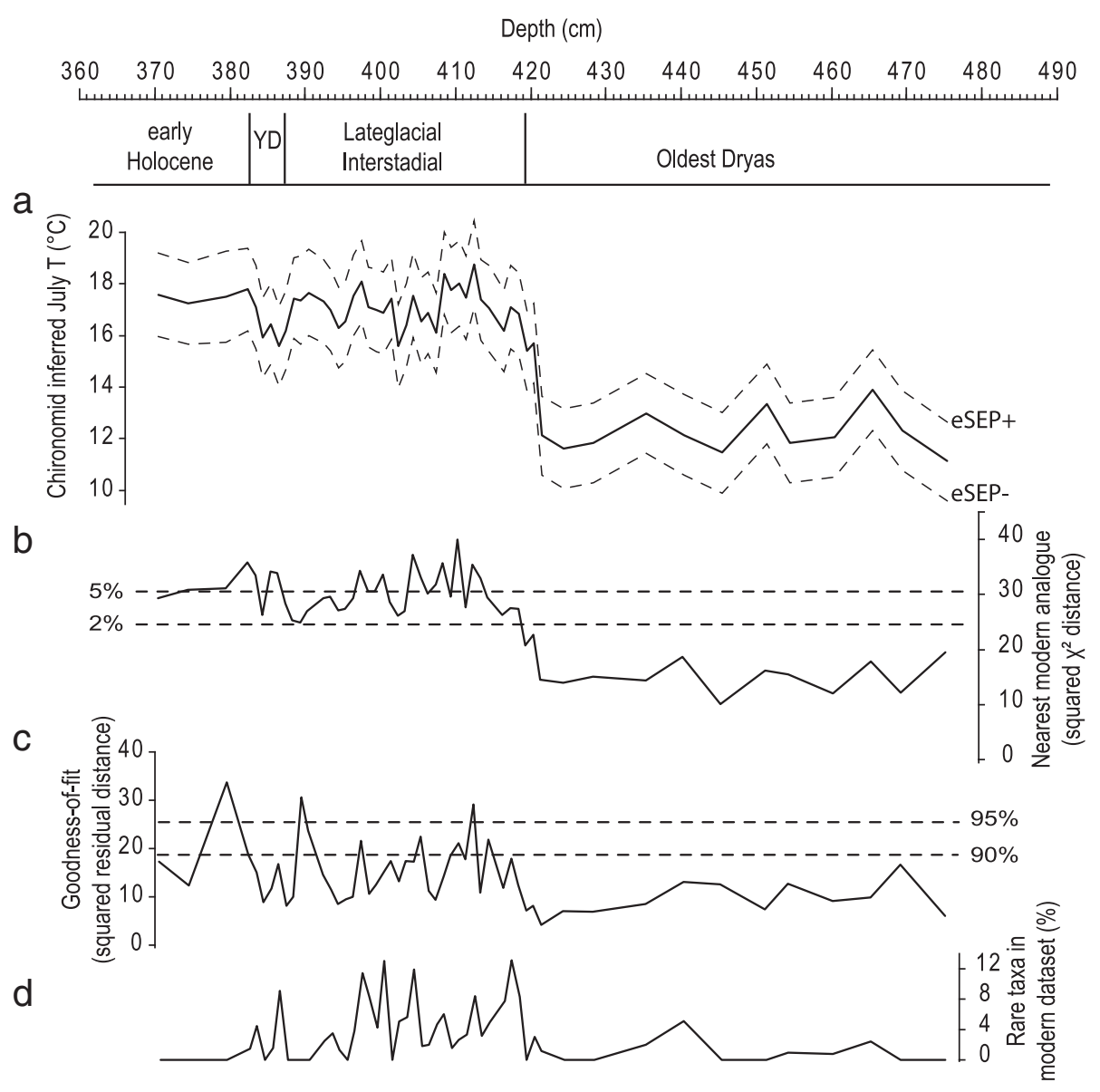

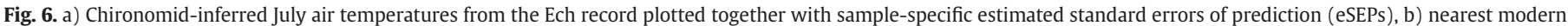

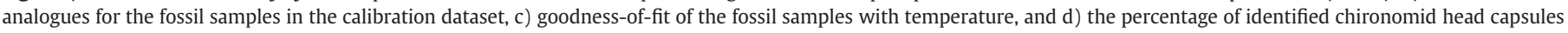

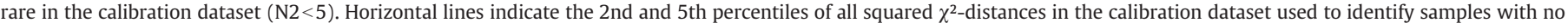

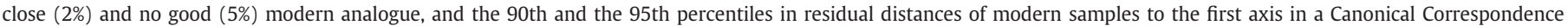

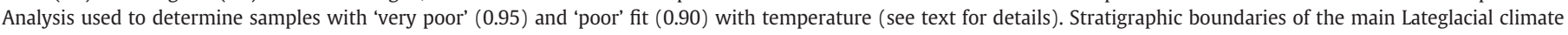
events are indicated (YD: Younger Dryas).

ranging from $14.8^{\circ} \mathrm{C}$ to $15.6{ }^{\circ} \mathrm{C}$ (mean: $15.2{ }^{\circ} \mathrm{C}$ ) during the Younger Dryas. At the beginning of the Holocene, July air temperature increased by about $2{ }^{\circ} \mathrm{C}$ to reach values around $17^{\circ} \mathrm{C}$.

Individual low counts (at 389.5 and $445.5 \mathrm{~cm}$ ) did not seem to induce a major bias in the reconstruction since the inferred temperatures for the corresponding samples did not significantly differ from the adjacent levels and/or they were consistent within a trend of temperature changes. The sample specific standard errors of prediction (eSEP) for the temperature reconstruction were between 1.52 and $1.77^{\circ} \mathrm{C}$. All taxa found in the Ech sediment sequence were included in the calibration data set. Taxa rare in the modern data set were present in the Ech fossil record at low percentages ranging from 0 to 13.2\% (Fig. 6). Samples of the Ech record generally have a good fit with temperature as estimated from the comparison between their residual distance to the first CCA axis with July air temperature as the only constraining factor and the 90th and 95th percentile of the residual distances of all the modern samples (Fig. 6). Only 3 samples $(379.5,389.5$ and $412.5 \mathrm{~cm})$ were found to have a very poor fit with temperature. The Oldest Dryas samples had good analogues in the modern calibration data. Indeed, their squared $\chi^{2}$-distances to the most similar modern samples were less than 20 , i.e. well below the 2nd percentile of all squared $\chi^{2}$-distances in the modern data set. This contrasted with the rest of the record (from the Interstadial to the early Holocene) in which all the fossil samples had no close or good analogue within the modern data set used for calibration (Fig. 6).

\section{Discussion}

The reliability of our Lateglacial summer temperature reconstruction must be carefully addressed for three main reasons:

(i) The chronology of the Ech record is based on a limited number of accepted radiocarbon dates and is mainly constrained by the palynostratigraphy. Even if this approach has given satisfying results in other studies (Heiri et al., 2007a, b; Lotter et al., in press), this can still possibly induce biases in the age assessment for some levels. More particularly, the age/depth relationship within the Lateglacial Interstadial is built from a linear interpolation. This implies a constant sediment accumulation rate, which may be regarded as unrealistic given the high environmental variability during this interval.

(ii) The transfer function used to infer summer air temperature from the Ech fossil chironomid record was based on modern calibration data from the Alps and Norway. The question therefore arises about the applicability of a mixed Swiss-Norwegian calibration data set to infer temperature from a Pyrenean record.

(iii) Apart from the Oldest Dryas/Interstadial transition, the magnitudes of changes in summer temperatures inferred from the Ech samples were low and remained in the range of the sample specific estimated standard errors of prediction of the inference model. In times of low amplitude temperature changes, local environmental and limnological factors may potentially control the chironomid response and lead to biases in temperature reconstructions (Velle et al., 2010). 
In order to validate the temperature reconstruction derived from Ech chironomid record, the following discussion comprises three sub-sections dealing with (i) the applicability of the combined Swiss-Norwegian transfer function to a Pyrenean record; (ii) the controlling factors of the Lateglacial chironomid succession from Ech (iii) the comparison of the reconstructed temperature with other similar studies in Europe and the Greenland $\delta^{18} \mathrm{O}$ record.

\subsection{Applicability of the transfer function}

To date, there is no modern training set published from the Pyrenean massif. The transfer function used in this study is based on the distribution of chironomid taxa in the Swiss Alps and in Norway.

The possibility of using a training set from one region to reconstruct climate in another region was previously addressed by Lotter et al. (1999) and Larocque-Tobler (2010). Both studies concluded that transfer functions from other regions can be applied, however the magnitude of changes should be taken with caution. LarocqueTobler (2010) indicated that fossil record and modern calibration data must share similar taxa. A representation of $80 \%$ of the taxa from the sediment record in the modern calibration data was suggested as a minimum criterion for the applicability of any transfer function. This quantitative prerequisite is met by the Ech chironomid record: all the fossil taxa are represented in the transfer function and total percentages of rare taxa in the transfer function are less than $14 \%$ in any of the Ech samples.

From the beginning of the Interstadial to the early Holocene, the fossil samples of the Ech record had no close or good analogue (assessed using a $\chi^{2}$-distance computation) in the modern calibration data used for the transfer function. Equivalent poor analogue situations were encountered for significant portions of fossil records located in the same region as the modern calibration data used to develop the transfer function (e.g. Ilyashuk et al., 2009; Larocque-Tobler et al., 2010). However, WA-PLS regression tends to perform well under noanalogue conditions, as long as the fossil taxa of high numerical importance are well-represented in the modern calibration dataset (Birks, 1998). The applicability of the mixed Swiss-Norwegian transfer function to the Ech fossil record is further supported by the goodness-of fit statistics as few samples are above the 0.90 and 0.95 percentile cut-levels set for samples with a poor and very poor fit with temperature (Fig. 6).

The other qualitative prerequisite for the applicability of the transfer function to the Ech fossil samples is a similar relationship of taxa with temperature between the Pyrenees and the modern calibration data. Lotter et al. (1999) found that the temperature optima of fossil taxa from North America and Europe were similar and highly correlated even from these two different biogeographical zones. Likewise, Heiri et al. (2011) demonstrate that the relationship of taxa to temperature is similar in the Norwegian and Swiss training sets used in the present study. Furthermore, in the early 70's, Laville (1971) carried out an extensive study of chironomid assemblages in nine Pyrenean lakes distributed along an altitude gradient. He concluded that, at that time, the lakes studied shared $85 \%$ of their chironomid species with lakes in the Alps. Moreover, his results showed that relative distribution of taxa with respect to altitude was similar between the two regions. The only difference was the higher altitude reached by taxa in the Pyrenees. This finding was taken as evidence of an influence of temperature on the chironomid distribution at a broad scale in the Alps and in the Pyrenees since climate is warmer in the Pyrenean Massif than in the Alps at equivalent altitude. It also implies that individual taxa have similar temperature preferences, irrespective of their geographical origin, in the Alps or the Pyrenees.

In summary, both quantitative (representation of fossil taxa in the transfer function and goodness of fit statistic) and qualitative interpretations (equivalent relationship of taxa towards temperature in the Pyrenees and in Swiss and Norwegian lakes) support the applicability of the Swiss/Norwegian transfer function to the Pyrenean Ech record.

\subsection{Controlling factors of the Ech chironomid succession during the Lateglacial}

In lakes, chironomid assemblages are affected by a variety of environmental conditions interacting in complex ecological processes (Brodersen and Quinlan, 2006; Velle et al., 2010; Eggermont and Heiri, 2011). In descending order of scale, from regional to ecosystem to microhabitat, the most commonly recognised influencing factors are temperature (Walker et al., 1991), trophic status (Brooks et al., 2001), oxygen conditions (Verneaux and Aleya, 1998), nature and amount of organic matter in the sediment (Brinkhurst, 1974; Verneaux and Aleya, 1998), and type of substrate (Mcgarrigle, 1980; Palomaki, 1989). Inferring temperature changes from a chironomid sequence using a transfer function assumes that the chironomid assemblages respond, directly or indirectly, to temperature. In times of low amplitude temperature changes, the influence of temperature may be masked by the influence of other environmental factors on the chironomid response as suggested by Velle et al. (2010) for some Holocene Fennoscandian records. The Lateglacial was characterised by much stronger changes in summer temperatures throughout the continent and most published chironomid-inferred temperature records are regionally consistent (Lang et al., 2010). Nevertheless, even in lateglacial records, temperature reconstruction can occasionally be compromised by the influence of local parameters on the chironomid fauna, as highlighted in the study of a lowland Mediterranean lake that experienced water-level fluctuations (Millet et al., 2007).

Since our main objective was to infer the lateglacial temperature from chironomids, the study site was chosen in order to maximise the climate influence on the chironomid community. In deep lakes, the relationship between subfossil chironomid assemblages and climate can be complicated by several interacting factors (e.g. Verbruggen et al., 2011): (1) the strong influence on the profundal community of oxygen conditions, food sources and quantity, and trophic functioning, (2) the bathymetric distribution of living larvae from the littoral to the deep zone, and (3) the variable redeposition of littoral remains in the deepest zones. In small and shallow systems, such as the Ech palaeolake, air temperature is expected to be an important, direct or indirect, influencing factor for distribution and abundance of chironomid taxa (Eggermont and Heiri, 2011). Furthermore, in these lakes the chironomid head capsules of the surface layers are to some extent redeposited and mixed and this reduces the spatial variation of living larvae within the lake (Brodersen and Lindeggard, 1997; Van Hardenbroek et al., 2011). Thus a single sample taken in the middle of the basin may be considered to be representative for the fauna of the entire lake.

Despite the study of a record which was a priori considered suitable for temperature reconstruction, the temperature influence on the chironomid succession in the Lateglacial should also be assessed with reference to known ecological preferences of the main taxa involved. The most striking feature of the Ech chironomid record is the distinct change of chironomid assemblages between Ecz-1 and Ecz-2 corresponding to the Oldest Dryas/Lateglacial Interstadial transition. During the Oldest Dryas, the chironomid community was dominated by Tanytarsus lugens-type, Chironomus anthracinus-type and Micropsectra insignilobus-type, taxa commonly found in modern lakes between 1500 and $2000 \mathrm{~m}$ in the Alps (Heiri and Lotter, 2010). In the Pyrenees, Laville (1971) studied the distribution of chironomid species among nine lakes from 2100 to $2400 \mathrm{~m}$ a.s.l. The species included Tanytarsus bathophilus (Tanytarsus lugens fossil morphotype) and Micropsectra contracta (Micropsectra insignilobus fossil morphotype), which were recognised as cold stenothermic species from their distribution in shallow cold lakes. 
The chironomid fauna of Ecz-2, characterised by taxa such as Tanytarsus pallidicornis-type II, Polypedilum nubeculosum-type, Glyptotendipes and Microtendipes was analogous to that of lowland and intermediate-altitude modern lakes in the Alps (Heiri and Lotter, 2010). Compared to taxa characterising the Oldest Dryas, taxa of Ecz-2 have warmer optima in modern training sets (e.g. Heiri et al., 2011). During Ecz-2, in addition to the influence of temperature, some local factors may have influenced individual taxa. For example, the increase in Glyptotendipes may have been linked to the growth of aquatic macrophytes (Pinder and Reiss, 1983; Klink and Moller Pillot, 2003), Microtendipes may have been favoured by the increase in sediment grain size and a higher proportion of coarse organic fragments (McGarrigle, 1980), and Polypedilum nubeculosum-type and Chironomus plumosus-type may have responded to the increase in organic matter in the sediment (Maitland, 1979; Wolfram, 1996; Millet et al., 2007). Nevertheless, the above mentioned taxa all have high temperature optima in both the Norwegian and Swiss calibration sets and so the overall influence of temperature change on the shift of the whole chironomid assemblage from Ecz-1 to Ecz-2 remains unquestionable even if local parameters may also account for some of the variability in particular taxa. Indeed, goodness-of-fit analysis shows that all but a few of the fossil samples in the entire sequence have a strong response to temperature.

The distribution of samples and taxa along axis 2 of the CA plot (Fig. 5) suggests that the chironomid response within Ecz-2 (from Ecz-2a to Ecz-2e) is more subtle compared to the major taxonomic turn-over at the Ecz-1/Ecz-2 transition. There is no clear relationship between taxon scores along axis 2 and their temperature optimum. This implies that the differences in the chironomid assemblages do not reflect different temperature conditions. Sample scores along axis 2 were also not correlated to LOI values during Ecz-2. These results suggest that multiple interacting factors probably controlled the chironomid succession depicted by the sample trajectory in the CA. In this context, trying to disentangle respective influence of temperature, habitat, and organic matter is difficult. Nevertheless, the high relative abundance of Tanytarsus lugens-type (up to 20\%) and correspondingly lower percentages of lowland taxa such as Chironomus plumosus-type, Polypedilum and Tanytarsus pallidicornistype during Ecz-2d, Ecz-2b and at the beginning of Ecz-2a suggest the prevalence of colder conditions during these phases.

The overall control of temperature on the assemblage changes is well established for the Oldest Dryas/Interstadial transition, but is more difficult to assess throughout the subbiozones of Ecz-2 when multiple factors probably interacted in complex processes. Therefore, the inference results will be further validated by comparison with other Lateglacial climate records.

\subsection{Comparison of the Ech temperature reconstruction with other European chironomid records and the Greenland $\delta^{18} \mathrm{O}$ record}

The chironomid-based temperature reconstruction from Ech displays the main lateglacial climate trends expected for the North Atlantic region as inferred by glacial and continental records. The succession through a cold Oldest Dryas (equivalent to GS-2 in NGRIP), a warmer Lateglacial Interstadial (GI-1 in NGRIP), a cold reversal during the Younger Dryas (GS-1 in NGRIP) and a warming at the beginning of the Holocene is clearly shown in the Ech record (Fig. 7). Furthermore, at the centennial-scale, the climate variability suggested by the Ech chironomid record is also in good agreement with the $\delta^{18} \mathrm{O}$ variations in the Greenland ice cores during the Lateglacial Interstadial (Fig. 7). The reconstruction of summer temperature changes derived from the Ech record can be compared to other available chironomid-based temperature reconstructions throughout Europe. In the following section, chironomid-inferred temperatures from other sites were re-calculated to the elevation of the Ech palaeolake using an altitudinal lapse rate of $0.6^{\circ} \mathrm{C} / 100 \mathrm{~m}$.

\subsubsection{The Oldest Dryas/Interstadial transition}

During the final part of the Oldest Dryas, the summer temperatures reconstructed at Ech were $2-3{ }^{\circ} \mathrm{C}$ lower than inferred from existing chironomids records in the Southern Alps (Table 3a,b). The temperature inferences from the Ech chironomids are in agreement

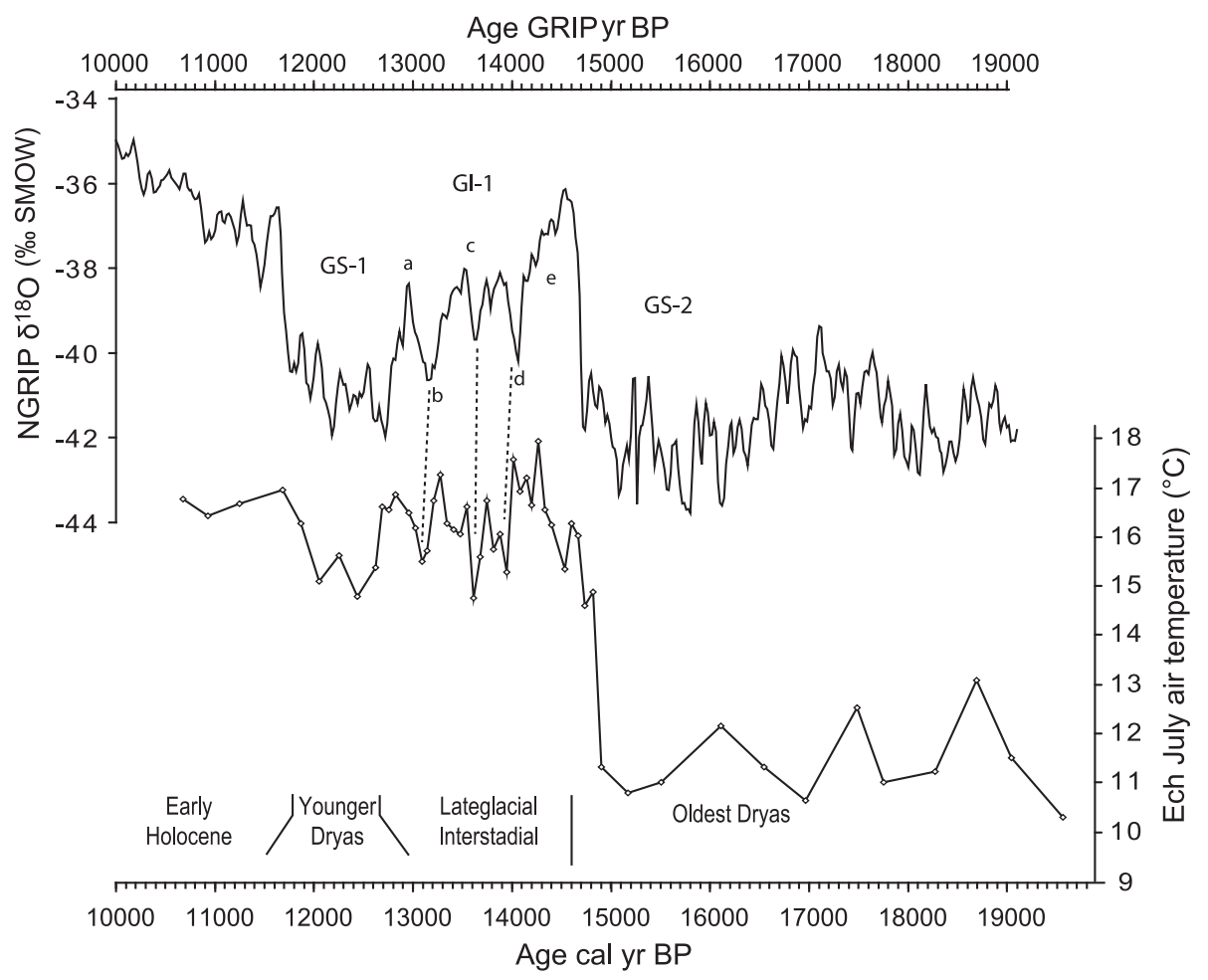

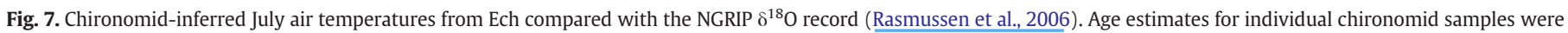
assigned from the age-depth model. 
Table 3a

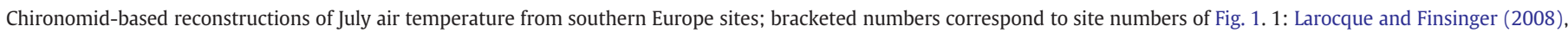
2: Heiri et al. (2007a, b).

\begin{tabular}{|c|c|c|c|c|c|c|c|}
\hline Site & Altitude & Latitude & Longitude & Oldest Dryas & Interstadial & Younger Dryas & Early Holocene \\
\hline Ech palaeolake & $710 \mathrm{~m}$ a.s.l & $43^{\circ} 04^{\prime} \mathrm{N}$ & $0^{\circ} 5^{\prime} \mathrm{W}$ & $11^{\circ} \mathrm{C}$ & $17.5-16.8^{\circ} \mathrm{C}$ & $15.2^{\circ} \mathrm{C}$ & $17^{\circ} \mathrm{C}$ \\
\hline Lago Piccolo di Avigliana (1) & $365 \mathrm{~m}$ a.s.l & $45^{\circ} 03 \mathrm{~N}$ & $7^{\circ} 23^{\prime} \mathrm{E}$ & $14^{\circ} \mathrm{C}$ & $16.7-15.5^{\circ} \mathrm{C}$ & $14^{\circ} \mathrm{C}$ & $16.5^{\circ} \mathrm{C}$ \\
\hline Lago di Lavarone (2) & $1100 \mathrm{~m}$ a.s.l & $45^{\circ} 56 \mathrm{~N}$ & $11^{\circ} 15^{\prime} \mathrm{E}$ & $13^{\circ} \mathrm{C}$ & $16.2-17.6^{\circ} \mathrm{C}$ & $15.6^{\circ} \mathrm{C}$ & $18.1-18.7^{\circ} \mathrm{C}$ \\
\hline
\end{tabular}

with the reconstructions derived from palaeobotanical data in the French and Spanish Pyrenees which indicate July temperature around $10.7^{\circ} \mathrm{C}$ in the region at the elevation of Ech (Renssen and Isarin, 2001).

At Ech, the temperature increase (ca. $6{ }^{\circ} \mathrm{C}$ ) at the Oldest Dryas/ Interstadial transition was almost twice as high as in chironomid records from southern Europe (Table 3b) and Switzerland (Egelsee, Larocque-Tobler et al., 2010; Gerzensee, Lotter et al., in press) and higher than the French Jura (Lake Lautrey, Heiri and Millet, 2005) where the amplitude of change in chironomid-inferred temperature was around $3-4{ }^{\circ} \mathrm{C}$ (Table $3 \mathrm{~b}$ ). An increase in summer temperature of around $6{ }^{\circ} \mathrm{C}$ in south-western France is consistent with the reconstructions and simulations carried out by Renssen and Isarin (2001). The Ech record provides new insights into the existence of a strong West-east gradient in July air temperature during the Oldest Dryas from the Atlantic margin (colder) to the Mediterranean regions (warmer) along latitudes $44-45^{\circ} \mathrm{N}$. During the Oldest Dryas, the Ech July air temperatures were probably influenced by the cold conditions prevailing over the North Atlantic Ocean. Indeed, during the Oldest Dryas the summer and winter sea-ice margins were inferred to be at approximately $60^{\circ} \mathrm{N}$ and $45^{\circ} \mathrm{N}$, respectively (Ruddiman and McIntyre, 1981; Renssen et al., 2002). Over the sea ice, the air was strongly cooled and consequently it was a potential source of cold air during summer for the west European coast.

\subsubsection{The Lateglacial Interstadial}

The temperatures reconstructed during the Interstadial were in the same range as in the existing chironomid-based reconstructions from the Southern Alps (Table 3a).

After the sharp rise corresponding to the Oldest Dryas/Interstadial transition, the inferred summer temperature continued increasing with a gentler slope, passing from $16{ }^{\circ} \mathrm{C}$ at the onset of the Interstadial to $17.5^{\circ} \mathrm{C}$ at ca. 14,100 cal yr BP. Given the uncertainties of the Ech record chronology, the hypothesis of a step-wise temperature reconstruction must be carefully addressed and supported by comparison with other climate records.

This seems similar to the two-step warming evidenced in some European oxygen isotope (Ammersee: von Grafenstein et al., 1999;

\section{Table 3b}

Magnitude of shifts in chironomid inferred temperature at the Oldest Dryas/Interstadial transition (OD/LI) and the Interstadial/Younger Dryas transition (LI/YD); bracketed numbers correspond to site numbers of Fig. 1. 1: Larocque and Finsinger (2008), 2: Heiri et al. (2007a, b), 3: Ilyashuk et al. (2009), 4: Heiri and Millet (2005), 5: Lotter et al. (in press), 6: Larocque-Tobler et al. (2010), 7: Heiri et al. (2007a, b), 8: Lang et al. (2010).

\begin{tabular}{lllll}
\hline Site & Latitude & Longitude & OD/LI & LI/YD \\
\hline Ech palaeolake & $43^{\circ} 04^{\prime} \mathrm{N}$ & $0^{\circ} 5^{\prime} \mathrm{W}$ & $+5 /+6{ }^{\circ} \mathrm{C}$ & $-1.5^{\circ} \mathrm{C}$ \\
Lago Piccolo & $45^{\circ} 03^{\prime} \mathrm{N}$ & $7^{\circ} 23^{\prime} \mathrm{E}$ & $+3{ }^{\circ} \mathrm{C}$ & $-1.5^{\circ} \mathrm{C}$ \\
$\quad$ di Avigliana (1) & & & & \\
Lago di Lavarone (2) & $45^{\circ} 56^{\prime} \mathrm{N}$ & $11^{\circ} 15^{\prime} \mathrm{E}$ & $+3{ }^{\circ} \mathrm{C}$ & $-2{ }^{\circ} \mathrm{C}$ \\
Maloja Pass (3) & $46^{\circ} 24^{\prime} \mathrm{N}$ & $9^{\circ} 41^{\prime} \mathrm{E}$ & & $-3.5^{\circ} \mathrm{C}$ \\
Lake Lautrey (4) & $46^{\circ} 35^{\prime} \mathrm{N}$ & $5^{\circ} 51^{\prime} \mathrm{E}$ & $+4 /+5{ }^{\circ} \mathrm{C}$ & $-2.5 /-3.5^{\circ} \mathrm{C}$ \\
Gerzensee (5) & $46^{\circ} 50^{\prime} \mathrm{N}$ & $7^{\circ} 33^{\prime} \mathrm{E}$ & $+2 /+3{ }^{\circ} \mathrm{C}$ & \\
Egelsee (6) & $47^{\circ} 11^{\prime} \mathrm{N}$ & $8^{\circ} 35^{\prime} \mathrm{E}$ & $+3 /+4{ }^{\circ} \mathrm{C}$ & $-1.5{ }^{\circ} \mathrm{C}$ \\
Hijkermeer (7) & $52^{\circ} 53^{\prime} \mathrm{N}$ & $6^{\circ} 29^{\prime} \mathrm{E}$ & & $-4{ }^{\circ} \mathrm{C}$ \\
North-west & $54^{\circ} 09^{\prime} \mathrm{N}-$ & $2^{\circ} 30^{\prime}$ & & $-3.8 /-4.5{ }^{\circ} \mathrm{C}$ \\
$\quad$ England (8) & $54^{\circ} 27^{\prime} \mathrm{N}$ & $\mathrm{W}-3^{\circ} 07^{\prime} \mathrm{W}$ & & \\
\hline
\end{tabular}

Hawes water: Marshall et al., 2002) and chironomid records (Lake Lautrey, Heiri and Millet, 2005). Nevertheless, the significance of this summer temperature increase at the beginning of the Interstadial still remains an open question. Indeed, this trend differs from the Greenland oxygen isotope records (Rasmussen et al., 2006) and from some European records (e.g. Eicher and Siegenthaler, 1976; Lotter et al., 1992) where the Oldest Dryas/Interstadial transition is marked by a single major abrupt warming shift in climate proxies. Apart from effective change in climate, the reconstruction of a gradual increase in temperature could potentially be explained by a time lag in the response of Ech chironomid assemblages to the warming at the Oldest Dryas/Interstadial transition. However, this temperature increase was not due to the appearance of new warm-adapted taxa but corresponded to a progressive decrease of taxa with cold optima (e.g. Tanytarsus lugens-type) and the corresponding increase in taxa with warmer optima, such as Tanytarsus pallidicornis-type II (Fig.4). This suggests the influence of continuous changing environment and/or climate influencing chironomid succession rather than an immigration lag of warm-adapted chironomid taxa. Indeed, the winged adults are dispersed widely by the wind and so chironomids can rapidly colonise lakes. Furthermore, the Ech Palaeolake was a mountain lake and it is expected that most temperate chironomid taxa were already present in the adjacent lowlands during the Oldest Dryas. Another alternative hypothesis would be the influence of other factors than temperature on chironomid succession at the beginning of the Interstadial. The trend in the temperature reconstruction (increase to reach around $17.5^{\circ} \mathrm{C}$ at ca. $14,000-14,200 \mathrm{cal} \mathrm{yr} \mathrm{BP}$ ) in the early Interstadial seems to follow closely an increase in organic matter in the sediment (Fig. 2). This trend in organic matter might originate from an increase in allochthonous inputs following soil and vegetation development on the watershed combined with a rise in autochthonous production following the abrupt warming of the onset of the Interstadial. Since organic matter is an important controlling factor for chironomid assemblages in lakes (Verneaux and Aleya, 1998), the increase in organic matter might have provoked some changes in chironomid assemblages indirectly linked with climate and this may have influenced the temperature reconstruction.

From ca. 14,100 cal yr BP onwards, a gradual decrease in the inferred summer temperature of ca. $1{ }^{\circ} \mathrm{C}$ until the end of the Interstadial is in accordance with numerous climate records including oxygen isotopes from Greenland (Rasmussen et al., 2006) and lake sediments (Lotter et al., 1992; Marshall et al., 2002), and temperature reconstructions from pollen (Peyron et al., 2005) and chironomids in England (Lang et al., 2010), Norway (Brooks and Birks, 2000), south-western Alps (Larocque and Finsinger, 2008) and Switzerland (Larocque-Tobler et al., 2010).

This gradual cooling throughout the Interstadial is punctuated by three short-duration cold events. They are broadly similar in magnitude (ca. $1.5^{\circ} \mathrm{C}$ ), which lies in the range of the error of prediction of the inference model (Fig. 6). Nevertheless, the concordance in the timing and amplitude of these events with climate changes reconstructed from other records in Europe highlights the sensitivity of the Ech temperature reconstruction. The short cooling events dated at ca. 13,900 cal yr BP and at ca. 13,100 cal yr BP may respectively correlate to the GI-1d event in the Greenland event stratigraphy (Lowe et al., 2008), equivalent to the Aegelsee Oscillation on the Swiss Plateau (Lotter et al., 1992), and to the GI-1b event (Lowe et al., 
2008), equivalent to the Gerzensee Oscillation (Lotter et al., 1992) (Fig. 7). The few existing chironomid-based reconstructions from mid-latitude Europe indicate a decrease in July air temperature of between 0.8 and $2.1{ }^{\circ} \mathrm{C}$ for these two events (reviewed in Ilyashuk et al., 2009; Lang et al., 2010). The decrease of $1.5^{\circ} \mathrm{C}$ in July air temperature inferred from the Ech chironomid record is in the upper range of these previous reconstructions. The third cold reversal occurred at ca. 13,600 cal yr BP, i.e. between the two previous centennial-scale cold events GI-1b and GI-1d (Fig. 7). It may be correlated with a short anomaly in $\delta^{18} \mathrm{O}$ in the Greenland ice-cores registered at a similar age within GI-1c (Fig. 7). Similarly, a rapid cooling event placed between GI-1b and GI-1d was also evidenced from chironomids in northwest England (LG-3 in Lang et al., 2010) but with a weaker reconstructed decrease in July air temperature (ca. $0.6-0.8^{\circ} \mathrm{C}$ ). These three cooling events during the Interstadial are also apparent in the chironomid-inferred temperature record from Whitrig Bog in southeast Scotland (Brooks and Birks, 2001).

\subsubsection{The Younger Dryas and the Early Holocene}

During the Younger Dryas, the temperatures inferred from the Ech chironomids were similar to other previous summer temperature reconstructions from sites located on the southern slope of the Alps (Table 3a). The temperature inferences for the early Holocene $\left(17^{\circ} \mathrm{C}\right)$ lie also in the range of these previous reconstructions (Table 3a). For both the Interstadial/Younger Dryas and Younger Dryas/Holocene transitions, changes in inferred-temperatures (i.e. $1.5-2{ }^{\circ} \mathrm{C}$ and $2.5^{\circ} \mathrm{C}$, respectively) were close to those reconstructed from chironomids at Lago di Lavarone and Lago Piccolo di Avigliana (Table 3a). The magnitudes of these temperature changes were smaller than those recorded at higher latitude in Europe (e.g. in northwest England, Lang et al., 2010, Western Norway, Brooks and Birks, 2000). The Ech temperature reconstruction agrees with the other available chironomid-based summer temperature reconstructions to indicate a continuous south to north gradient in the amplitude of the Younger Dryas cooling (Table 3b). These findings are also in close agreement with climate simulations and reconstructions presented in Renssen and Isarin (2001) which showed a clear N-S gradient in the magnitude of temperature changes associated to the "11.7 ka transition".

This points to the absence of local interference into large-scale climate forcing factors (linking insolation, ocean and atmosphere), contrary to the Oldest Dryas where sea ice apparently strongly influenced local climate along Atlantic coast.

\section{Conclusion}

This paper presents the first study of Lateglacial chironomids in the Pyrenees, a region where quantitative climate reconstructions are still rare. Temperature change was found to be the main controlling factor for the Ech chironomid assemblage during the Lateglacial even if assemblage changes may also have been mediated by other local conditions. This implies that temperature reconstruction based on changes in chironomid assemblages was justified. The feasibility of quantitative reconstruction using a merged Swiss-Norwegian training set was supported by the good error and prediction statistics of the model and the similarity in ecological preferences of the main taxa between Norway, the Alps and the Pyrenees.

The model reconstructed July air temperatures between 10 and $13^{\circ} \mathrm{C}$ during the Oldest Dryas, a two-step increase in temperatures to 16 and $17.5^{\circ} \mathrm{C}$ during the first part of the Interstadial, followed by a decrease to $16.5^{\circ} \mathrm{C}$ by the end of the Interstadial. Inferred temperatures decreased to $15-15.5^{\circ} \mathrm{C}$ during the Younger Dryas, and reached ca. $17{ }^{\circ} \mathrm{C}$ at the beginning of the Holocene. Superimposed on the changes in temperature corresponding to the major lateglacial events, climate variability at a centennial-scale is further suggested by the Ech record.
During the Interstadial, the Ech record features three centennialscale coolings of ca. $1.5^{\circ} \mathrm{C}$ amplitude. The older (ca. 13,900 cal yr BP) may correlate with the GI-1d event in the Greenland event stratigraphy (Lowe et al., 2008), equivalent to the Aegelsee Oscillation (Lotter et al., 1992). The younger short-lived cold oscillation (at ca. 13,100 cal yr BP) may be related to the GI-1b event (Lowe et al., 2008), equivalent to the Gerzensee Oscillation (Lotter et al., 1992). The third cold reversal, ca. 13,600 cal yr BP, may correlate with a short anomaly in $\delta^{18} \mathrm{O}$ in the Greenland ice-cores at a similar age within GI-1c. The reliability of the reconstruction was highlighted by the overall good concordance of the inferred temperatures with other Lateglacial climate records from southern and mid-latitude Europe and from the Greenland ice cores.

Although a single site is insufficient to fill the lack of quantitative climate data from southern Europe, the new summer temperature reconstruction based on the Ech chironomid succession complements previous published records and extends the available data-set describing climate change over Europe. The Ech record provided new insights on the existence of a strong West-east gradient in July air temperature during the Oldest Dryas from the Atlantic margin (colder) to the Mediterranean region (warmer) along $44-45^{\circ} \mathrm{N}$. At the beginning of the Interstadial, the distribution of July temperature throughout Europe changed and became similar in pattern to the present situation characterised by a north-south thermal gradient. At Ech, the Younger Dryas cooling was similar in magnitude to that inferred from other sites on the southern slope of the Alps, but smaller than those inferred from sites in northern Europe. The Ech temperature reconstruction agrees with the other available chironomidbased summer temperature reconstructions and indicates a strong south to north gradient of increasing amplitude of the Younger Dryas cooling across Europe.

\section{Acknowledgements}

This research was supported by the research initiative European climate change at the end of the last glaciation (EUCLIM) headed by O. Heiri and A.F. Lotter, the Nederlandse Organisatie voor Wetenschappelijk Onderzoek, Aard- en Levenswetenschappen (NWO-ALW grant 818.01.001), the Communauté de Travail des Pyrénées and the project ANPYR (FEDER/National Park of the Western Pyrenees) headed by D. Galop.

\section{References}

Agustì-Panareda, A., Thompson, R., 2002. Reconstructing air temperature at eleven remote Alpine and Arctic lakes in Europe from 1781 to 1997. Journal of Paleolimnology 28, 7-23.

Allen, I.R.M., Huntley, B., Watts, W.A., 1996. The vegetation and climate of northwest Iberia over the last 14,000 yr. Journal of Quaternary Science 11 (2), 125-147.

Aubert, S., Belet, J.M., Bouchette, A., Otto, T., Dedoubat, J.J., Fontugne, M., Jalut, G., 2004. Dynamique tardiglaciaire et holocène de la végétation à l'étage montagnard dans les Pyrénées Centrales. Comptes Rendus Biologies 327, 381-388.

Battarbee, R.W., 2000. Paleolimnological approaches to climate change, with special regard to the biological record. Quaternary Science Reviews 19, 107-124.

Birks, H.J.B., 1998. Numerical tools in palaeolimnology-progress, potentialities, and problems. Journal of Paleolimnology 20, 307-332.

Birks, H.J.B., Line, J.M., Juggins, S., Steveson, A.C., ter Braak, C.J.F., 1990. Diatoms and pH reconstruction. Philosophical Transactions of the Royal Society of London B 327, 263-278.

Brinkhurst, R.O., 1974. The Benthos of Lakes. Macmillan Press Ltd., London.

Brodersen, K.P., Lindeggard, C., 1997. Significance of subfossil chironomid remains in classification of shallow lakes. Hydrobiologia 342 (343), 125-132.

Brodersen, K.P., Quinlan, R., 2006. Midges as palaeoindicators of lake productivity, eutrophication and hypolimnetic oxygen. Quaternary Science Reviews 25, 1995-2012.

Brooks, S.J., 2006. Fossil midges (Diptera: Chironomidae) as palaeoclimatic indicators for the Eurasia region. Quaternary Science Reviews 25, 1894-1910.

Brooks, S.J., Birks, H.J.B., 2000. Chironomid-inferred Lateglacial and early-Holocene mean July air temperatures for Kråkenes Lake, western Norway. Journal of Paleolimnology 23, 77-89.

Brooks, S.J., Birks, H.J.B., 2001. Chironomid-inferred air temperatures from Lateglacial and Holocene sites in north-west Europe: progress and problems. Quaternary Science Reviews 20,1723-1741. 
Brooks, S.J., Birks, H.J.B., 2004. The dynamics of Chironomidae (Insecta : Diptera) assemblages in response to environmental change during the past 700 years on Svalbard. Journal of Paleolimnology 31, 483-498.

Brooks, S.J., Bennion, H., Birks, H.J.B., 2001. Chironomid- and diatom-phosphorus inference models and their application to a sediment core from Betton Pool, Shropshire, England. Freshwater Biology 46, 511-532.

Brooks, S.J., Langdon, P.G., Heiri, O., 2007. The identification and use of Palaearctic Chironomidae larvae in palaeoecology. Quaternary Research Association Technical Guide, London.

Chessel, D., Dufour, A.B., Thioulouse, J., 2004. The ade4 package-I- One-table methods. R News 4, 5-10.

Dormoy, I., Peyron, O., Combourieu Nebout, N., Goring, S., Kotthoff, U., Magny, M., Pross, J., 2009. Terrestrial climate variability and seasonality changes in the Mediterranean region between 15000 and 4000 a BP deduced from marine pollen records. Climate of the past 5, 615-632.

Dupias, G., 1985. Végétation des Pyrénées. Notice détaillée de la partie pyrénéenne des feuilles $(69,70,71,72,76,77,78)$. CNRS, Paris. 209 pp.

Eggermont, H., Heiri, O., 2011. The chironomid-temperature relationship: expression in nature and palaeoenvironmental implications. Biological Reviews. doi:10.1111/ j.1469-185X.2011.00206.x.

Eicher, U., Siegenthaler, U., 1976. Palynological and isotope investigations on LateGlacial sediment cores from Swiss lakes. Boreas 5, 109-117.

Gavin, D., 2001. Estimation of inbuilt age in radiocarbon ages of soil charcoal for fire history studies. Radiocarbon 43, 27-44.

González-Samperíz, P., Valéro-Garcés, B.L., Moreno, A., Jalut, G., García-Ruíz, J.M., Martí-Bono, C., Delgado-Huerta, A., Otto, T., Dedoubat, J.J., 2006. Climate variability in the Spanish Pyrenees for the last $30,000 \mathrm{yr}$ : El Portalet peatbog sequence. Quaternary Research 66, 38-52.

Grafenstein, U., Erlenkeuser, H., Brauer, A., Jouzel, J., Johnsen, S., 1999. A mid-European decadal isotope climate record from 15,500 to 5,000 years BP. Science 284, 1654-1657.

Grimm, E.C., 2004. TGView Version 2.0.2. Illinois State Museum, Research and Collections Center, Springfield.

Heiri, O., Lotter, A.F., 2001. Effect of low count sums on quantitative environmental reconstructions: an example using subfossil chironomids. Journal of Paleolimnology $26,343-350$.

Heiri, O., Lotter, A.F., 2005. Holocene and Lateglacial summer temperature reconstruction in the Swiss Alps based on fossil assemblages of aquatic organisms: a review. Boreas 34, 506-516.

Heiri, O., Lotter, A.F., 2010. How does taxonomic resolution affect chironomid-based temperature reconstruction? Journal of Paleolimnology 44, 589-601.

Heiri, O., Millet, L., 2005. Reconstruction of Late Glacial summer temperatures from chironomid assemblages in Lac Lautrey (Jura, France). Journal of Quaternary Science 20, 33-44.

Heiri, O., Lotter, A.F., Lemcke, G., 2001. Loss on ignition as a method for estimating organic and carbonate content in sediments: reproducibility and comparability of results. Journal of Paleolimnology 25, 101-110.

Heiri, O., Lotter, A.F., Hausmann, S., Kienast, F., 2003. A chironomid-based Holocene summer air temperature reconstruction from the Swiss Alps. The Holocene 13 (4), 477-484.

Heiri, O., Filippi, M.L., Lotter, A.F., 2007a. Lateglacial summer temperature in the Trentino area (Northern Italy) as reconstructed by fossil chironomid assemblages in Lago di Lavarone (1100 $\mathrm{m}$ a.s.l.). Studi Trentini di Scienze Naturali. Acta Geologica 82, 299-308.

Heiri, O., Cremer, O., Engels, S., Hoek, W.Z., Peeters, W., Lotter, A.F., 2007b. Lateglacial summer temperatures in the Northwest European lowlands: a chironomid record from Hijkermeer, the Netherlands. Quaternary Science Reviews 26, 2420-2437.

Heiri, O., Brooks, S., Birks, H.J.B., Lotter, A.F., 2011. A 274-lake calibration dataset and inference model for chironomid-based summer temperature reconstruction in Europe. Quaternary Science Reviews 30, 3445-3456.

Hill, M.O., 1973. Diversity and evenness: a unifying notation and its consequences. Ecology 54, 427-432.

Ilyashuk, B.P., Gobet, E., Heiri, O., Lotter, A.F., van Leeuwen, J.F.N., van der Knaap, W.O., Ilyashuk, E.A., Oberli, F., Ammann, B., 2009. Lateglacial environmental and climatic changes at the Maloja Pass (1865 m a.s.l., Central Swiss Alps) as recorded by chironomids and pollen. Quaternary Science Reviews 28, 1340-1353.

Jalut, G., Andrieu, V., Delibrias, G., Fontugne, M., Pagès, P., 1988. Palaeoenvironment of the valley of Ossau (Western French Pyrénées) during the last 27000 years. Pollen et Spores 30 (3-4), 357-394.

Jalut, G., Montserrat Marti, J., Fontugne, M., Delibrias, G., Vilaplana, J.M., Julia, R., 1992. Glacial to Interglacial vegetation changes in the northern and southern Pyrénées : deglaciation, vegetation cover and chronology. Quaternary Science Reviews 11, 449-480.

Jalut, G., Aubert, S., Galop, D., Fontugne, M., Belet, J.M., 1996. Type regions F-zg and F-r, the northern slope of the Pyrenees. In: Berglung, B.E., Birks, H.J.B., Ralska-Jaziewiczowa, M., Wright, H.E. (Eds.), Palaeoecological Events During the Last 15000 years-Regional Syntheses of Palaeoecological Studies of Lakes and Mires in Europe. Wiley J. \& Sons, pp. 612-632.

Jones, V.I., Juggins, S., 1995. The construction of a diatom-based chlorophyll a transfer function and its application at three lakes on Signy Island (maritime Antarctic) subject to differing degrees of nutrient enrichment. Freshwater Biology 34, 433-445.

Juggins, S., 2003. C2 User Guide. Software for Ecological and Palaeoecological Data Analysis and Visualisation. University of Newcastle, Newcastle upon Tyne.

Klink, A.G., Moller Pillot, H.K.M., 2003. Chironomidae larvae. Key to the higher taxa and species of the lowlands of Northwestern Europe. World Biodiversity Database
CD-ROM series. Expert Center for Taxonomic Identification, University of Amsterdam, Amsterdam.

Lang, B., Brooks, S.J., Bedford, A., Jones, R.T., Birks, H.J.B., 2010. Regional consistency in Lateglacial chironomid-inferred temperatures from five sites in north-west England. Quaternary Science Reviews 29, 1528-1538.

Larocque, I., Finsinger, W., 2008. Late-glacial chironomid-based temperature reconstructions for Lago Piccolo di Avigliana in the southwestern Alps (Italy). Palaeogeography, Palaeoclimatology, Palaeoecology 257, 207-223.

Larocque-Tobler, I., 2010. Reconstructing temperature at Egelsee, Switzerland, using North American and Swedish chironomid transfer functions: potential and pitfalls. Journal of Paleolimnology 44, 243-251.

Larocque-Tobler, I., Heiri, O., Wehrli, M., 2010. Late Glacial and Holocene temperature changes at Egelsee, Switzerland, reconstructed using subfossil chironomids. Journal of Paleolimnology 43, 649-666.

Laville, H., 1971. Recherches sur les chironomids (Diptera) lacustres du massif de Néouvielle (Hautes-Pyrénées). Première partie : systématique, écologie, phénologie. Annales de Limnologie 10 (2), 163-171.

Lotter, A.F., Eicher, U., Birks, H.J.B., Siegenthaler, U., 1992. Lateglacial climatic oscillations as recorded in Swiss lake sediments. Journal of Quaternary Science 7 , $\underline{187-204 .}$

Lotter, A.F., Walker, I.R., Brooks, S.J., Hofmann, W., 1999. An intercontinental comparison of chironomid palaeotemperature inference models: Europe vs North America. Quaternary Science Reviews 18, 717-735.

Lotter, A.F., Heiri, O., Brooks, S.J., van Leeuwen, J.F.N., Eicher, U., Ammann, B., in press. Rapid summer temperature changes during Termination 1a: high-resolution multi-proxy climate reconstructions from Gerzensee (Switzerland). Quaternary Science Reviews. doi:10.1016/j.quascirev.2010.06.022.

Lowe, J.J., Rasmussen, S.O., Björck, S., Hoek, W.Z., Steffensen, J.P., Walker, M.J.C., Yu, Z.C. 2008. the INTIMATE group, 2008. Synchronisation of palaeoenvironmental events in the North Atlantic region during the Last Termination: a revised protocol recommended by the INTIMATE group. Quaternary Science Reviews 27, 6-17.

Maitland, P.S., 1979. The distribution of zoobenthos and sediments in Loch Leven, Kinross, Scotland. Archiv für Hydrobiologie 85, 98-125.

Marshall, J.D., Jones, R.T., Crowley, S.F., Oldfield, F., Nash, S., Bedord, A., 2002. A high resolution Late-Glacial isotopic record from Hawes Water, northwest Englandclimatic oscillations: calibration and comparison of palaeotemperature proxies. Palaeogeography, Palaeoclimatology, Palaeoecology 185, 25-40.

Mcgarrigle, M.L., 1980. The distribution of chironomid communities and controlling sediment parameters in L. Derravaragh, Ireland. In: Murray, D.A. (Ed.), Chironomidae. Ecology, Systematics, Cytology and Physiology. Pergamon Press, Oxford, pp. 275-282.

Millet, L., Vannière, B., Verneaux, V., Magny, M., Disnar, J.R., Laggoun-Defarge, F., Walter-Simonnet, A.V., Ortu, E., Bossuet, G., De Beaulieu, J.L., 2007. Response of littoral chironomid communities and organic matter to late glacial lake-level, vegetation and climate changes at Lago dell'Accesa (Tuscany, Italy). Journal of Paleolimnology 38, 525-539.

Muñoz-Sobrino, C., Ramil-Rego, P., Gómez-Orellana, L., 2007. Late Würm and early Holocene in the mountains of northwest Iberia: biostratigraphy, chronology and tree colonization. Vegetation History and Archaeobotany 16, 223-240.

Ortu, E., Peyron, O., Bordon, A., de Beaulieu, J.L., Siniscalco, C., Caramiello, R., 2008. Lateglacial and Holocene climate oscillations in the South-western Alps: an attempt at quantitative reconstruction. Quaternary International 190, 71-88.

Palomaki, R., 1989. The chironomid larvae in the different depth zones of the littoral in some Finnish lakes. Acta Biologica Debrecina Oecologica Hungarica. 3, 257-266.

Peyron, O., Bégeot, C., Brewer, S., Heiri, O., Magny, M., Millet, L., Ruffaldi, P., Van Campo, E., Yu, G., 2005. Lateglacial climate in the Jura Mountains based on pollen, lakelevels, and chironomids. Quaternary Research 64, 197-211.

Pinder, L.C.V., Reiss, F., 1983. The larvae of Chironominae (Diptera: Chironomidae) of the Holarctic region-key and diagnoses. Entomologica Scandinavica Supplement 19, 293-435.

Rasmussen, S.O., Andersen, K.K., Svensson, A.M., Steffensen, J.P., Vinther, B.M., Clausen, H.B., Siggaard-Andersen, M.-L., Johnsen, S.J., Larsen, L.B., Dahl-Jensen, D., Bigler, M., Röthlisberger, R., Fischer, H., Goto-Azuma, K., Hansson, M.E., Ruth, U., 2006. A new Greenland ice core chronology for the last glacial termination. Journal of Geophysica Research 111, D06102. doi:10.1029/2005JD006079.

Reille, M., Andrieu, V., 1995. The late Pleistocene and Holocene in the Lourdes Basin, Western Pyrénées, France: new pollen analytical and chronological data. Vegetation History and Archaeobotany 4, 1-21.

Reimer, P.J., Baillie, M.G.L., Bard, E., Bayliss, A., Beck, J.W., Blackwell, P.G., Bronk Ramsey, C., Buck, C.E., Burr, G.S., Edwards, R.L., Friedrich, M., Grootes, P.M., Guilderson, T.P., Hajdas, I., Heaton, T.J., Hogg, A.G., Hughen, K.A., Kaiser, K.F., Kromer, B., McCormac F.G., Manning, S.W., Reimer, R.W., Richards, D.A., Southon, J.R., Talamo, S., Turney, C.S.M., van der Plicht, J., Weyhenmeyer, C.E., 2009. IntCal09 and Marine09 radiocarbon age calibration curves, 0-50,000 years cal BP. Radiocarbon 51, 1111-1150.

Renssen, H., Isarin, R.F.B., 2001. The two major warming phases of the last deglaciation at 14.7 and $11.5 \mathrm{ka}$ cal yr BP in Europe: climate reconstruction and AGCM experiments. Global and Planetary Change 30, 117-153.

Renssen, H., Isarin, R.F.B., Vandenberghe, J., 2002. Thermal gradients in Europe during the last glacial-interglacial transition. Geologie en Mijnbouw-Netherland Journal of Geosciences 81, 113-122.

Ruddiman, W.F., McIntyre, A., 1981. The North Atlantic Ocean during the last deglaciation. Palaeogeography, Palaeoclimatology, Palaeoecology 35, 145-214.

Stuiver, M., Reimer, P.J., 1993. Extended ${ }^{14} \mathrm{C}$ data base and revised CALIB $3.0{ }^{14} \mathrm{C}$ age calibration program. Radiocarbon 35, 215-230.

ter Braak, C.J.F., Juggins, S., 1993. Weighted averaging partial least squares regression (WA-PLS): an improved method for reconstructing environmental variables from species assemblages. Hydrobiologia 269 (270), 485-502. 
ter Braak, C.J.F., Smilauer, P., 2002. CANOCO Reference Manual and CanoDraw for Windows user's guide. Biometris, Wageningen.

ter Braak, C.J.F., Juggins, S., Birks, H.J.B., van der Voet, H., 1993. Weighted averaging partial least squares regression (WA-PLS): definition and comparison with other methods for species-environmental calibration. In: Patil, G.P., Rao, C.R. (Eds.), Multivariate Environmental Statistics. Elsevier Science Publishers, Amsterdam, pp. 525-560.

van Hardenbroek, M., Heiri, O., Wilhelm, M.F., Lotter, A.F., 2011. How representative are subfossil assemblages of Chironomidae and common benthic invertebrates for the living fauna of Lake De Waay, the Netherlands? Aquatic Sciences 73, 247-259.

Velle, G., Brodersen, K.P., Birks, H.J.B., Willassen, E., 2010. Midges as quantitative temperature indicator species: lessons for Palaeoecology. The Holocene 20 989-1002.

Verbruggen, F., Heiri, O., Meriläinen, J.J., Lotter, A.F., 2011. Subfossil chironomid assemblages in deep, stratified European lakes: relationships with temperature, trophic state and oxygen. Freshwater Biology 56, 407-423.
Verneaux, V., Aleya, L., 1998. Bathymetyric distributions of chironomid communities in ten French lakes: implications on lake classification. Archiv für Hydrobiologie 142, 209-228.

Walker, I.R., 2001. 3- Midges: Chironomidae and related Diptera. In: Last, W.M., Smol, J.P. (Eds.), Tracking Environmental change using lake sediments. Zoological Indicators, Volume 4. Kluwer Academic Publishers, Dordrecht, pp. 43-66.

Walker, I.R., Smol, J.P., Engstrom, D.R., Birks, H.J.B., 1991. An assessment of Chironomidae as quantitative indicators of past climatic change. Canadian Journal of Fisheries and Aquatic Sciences 48, 975-987.

Wiederholm, T., 1983. Chironomidae of the Holarctic region. Keys and Diagnoses. Part 1. Larvae. Entomologica Scandinavica Supplement 19, 1-457.

Wolfram, G., 1996. Distribution and production of chironomids (Diptera: Chironomidae) in a shallow, alkaline lake (Neusiedler See, Austria). Hydrobiologia 318, 103-115. 